Open Access

\title{
Tissue biodistribution of intravenously administrated titanium dioxide nanoparticles revealed blood-brain barrier clearance and brain inflammation in rat
}

Clémence Disdier ${ }^{1}$, Jérôme Devoy ${ }^{2}$, Anne Cosnefroy $^{1}$, Monique Chalansonnet $^{2}$, Nathalie Herlin-Boime ${ }^{3}$, Emilie Brun ${ }^{4}$, Amie Lund ${ }^{5}$ and Aloïse Mabondzo ${ }^{1 *}$

\begin{abstract}
Background: Notwithstanding increasing knowledge of titanium dioxide nanoparticles $\left(\mathrm{TiO}_{2} \mathrm{NPs}\right)$ passing through biological barriers, their biodistribution to the central nervous system (CNS) and potential effects on blood-brain barrier (BBB) physiology remain poorly characterized.

Methods: Here, we report time-related responses from single-dose intravenous (IV) administration of $1 \mathrm{mg} / \mathrm{kg} \mathrm{TiO}_{2}$ NPs to rats, with particular emphasis on titanium (Ti) quantification in the brain. Ti content in tissues was analyzed using inductively coupled plasma mass spectrometry. Integrity and functionality of the BBB as well as brain inflammation were characterized using a panel of methods including RT-PCR, immuno-histo chemistry and transporter activity evaluation.

Results: Biokinetic analysis revealed Ti biopersistence in liver, lungs and spleen up to one year after $\mathrm{TiO}_{2} \mathrm{NPs}$ administration. A significant increase of $\mathrm{Ti}$ in the brain was observed at early end points followed by a subsequent decrease. In-depth analysis of $\mathrm{Ti}$ in the total brain demonstrated quantitative Ti uptake and clearance by brain microvasculature endothelial cells (BECS) with minimal translocation in the brain parenchyma. The presence of $\mathrm{Ti}$ in the BECs did not affect BBB integrity, despite rapid reversible modulation of breast cancer resistance protein activity. Ti biopersistence in organs such as liver was associated with significant increases of tight junction proteins (claudin-5 and occludin), interleukin $1 \beta$ (IL-1 $\beta$ ), chemokine ligand 1 (CXCL1) and $\gamma$ inducible protein-10 (IP-10/CXCL10) in BECs and also increased levels of IL-1 $\beta$ in brain parenchyma despite lack of evidence of $\mathrm{Ti}$ in the brain. These findings mentioned suggest potential effect of Ti present at a distance from the brain possibly via mediators transported by blood. Exposure of an in vitro BBB model to

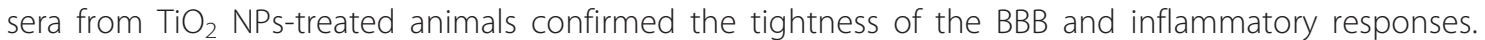

Conclusion: Overall, these findings suggest the clearance of $\mathrm{TiO}_{2} \mathrm{NPs}$ at the BBB with persistent brain inflammation and underscore the role of Ti biopersistence in organs that can exert indirect effects on the CNS dependent on circulating factors.

\footnotetext{
* Correspondence: aloise.mabondzo@cea.fr

'CEA, Direction des Sciences du Vivant, iBiTec-S, Service de Pharmacologie et d'Immunoanalyse, Equipe Pharmacologie Neurovasculaire, 91191 Gif-sur-Yvette, France

Full list of author information is available at the end of the article
} 


\section{Background}

Titanium dioxide $\left(\mathrm{TiO}_{2}\right)$ nanoparticles (NPs) are the second most frequently used NPs in industry worldwide (http://www.nanotechproject.org). $\mathrm{TiO}_{2}$ is widely used as a white pigment in paint, ink, plastic, and paper and as food additive, while the nanosized $\mathrm{TiO}_{2}$ is also used for its photocatalytic activity in self-cleaning materials and for its $\mathrm{UV}$ absorption capacity in sunscreen cosmetics $[1]$. $\mathrm{TiO}_{2}$ is also used in the composition of dental prosthesis and implant biomaterials. Because of these multiple applications, $\mathrm{TiO}_{2}$ is massively produced and as nano-sized particles is found in variable proportions in daily life products. For example, for food grade $\mathrm{TiO}_{2}$ (E171) fraction of particles under $100 \mathrm{~nm}$, thus corresponding to the strict definition of NPs was estimated at $36 \%$ by Weir et al. and 5-10\% reported by Peters et al. [2, 3].

Recent toxicological and pharmacological research on rodents has shown that $\mathrm{TiO}_{2} \mathrm{NPs}$ may translocate across physiological barriers such as respiratory, intestinal and vascular epithelium and therefore reach various organs and tissues including the brain [4-6]. The brain is well protected by the blood brain barrier (BBB), which contains cells of several types: brain endothelial cells (BECs), astrocytes, and pericytes [7-11]. These cells communicate closely to guarantee a physical and functional barrier between the blood and the central nervous system (CNS): tight junctions connecting endothelial cells and many transporters including two major ATP-driven drug efflux pumps, the P-glycoprotein (P-gp) and breast cancer resistant protein (BCRP) [12-14]. This neurovascular unit regulates distribution of xenobiotics to the brain.

Fabian et al. reported a lack of translocation of $20 \mathrm{~nm}$ $\mathrm{TiO}_{2}$ NPs to the brain parenchyma $24 \mathrm{~h}$ after intravenous (IV) injection of a dose of $5 \mathrm{mg} / \mathrm{kg}$ to rats [15]. These findings are further supported by other studies results in which lack of brain distribution was noticed $6 \mathrm{~h}$ following IV administration of $0.95 \mathrm{mg} / \mathrm{kg}$ of Degussa P25 $\mathrm{TiO}_{2}$ NPs to rats [16] and 24 h after administration of a $10 \mathrm{mg} / \mathrm{kg}$ dose of rutile $\mathrm{TiO}_{2} \mathrm{NPs}$ to mice [17]. However, Geraets et al. showed the presence of $\mathrm{TiO}_{2}$ NPs of different sizes and crystalline forms $24 \mathrm{~h}$ after a $5 \mathrm{mg} / \mathrm{kg}$ IV dose in the brain of rats [18]. While brain translocation of $\mathrm{TiO}_{2}$ NPs after IV administration remains contradictory, oral and pulmonary exposure in rodents has shown distribution of $\mathrm{TiO}_{2}$ NPs to the CNS $[18,19]$. Disturbance of neurotransmitters and enzymes, oxidative stress and inflammatory response have been described as neurotoxic effects after nasal instillation, intraperitoneal injection, oral administration or prenatal exposure [20-25]. These findings raised the question of the entry of $\mathrm{TiO}_{2}$ NPs into the brain and of their interactions with the BBB.

Our previous data using an in vitro BBB model [26] show that P25 $\mathrm{TiO}_{2}$ NPs $(21.5 \mathrm{~nm}, 75-25 \%$ anatase/ rutile) can accumulate in BECs, with very low and limited translocation in the glial cells, hinting at the "physical barrier" role of the BEC epithelium [27]. Overall, these contradictory in vitro and in vivo findings show that additional investigations are needed to ascertain in vivo brain translocation of $\mathrm{TiO}_{2}$ NPs, interactions between $\mathrm{TiO}_{2} \mathrm{NPs}$ and the $\mathrm{BBB}$, and potential adverse effects in the brain. These are the main subjects of the present study.

We used well-characterized anatase/rutile $\mathrm{TiO}_{2}$ NPs (P25 aeroxide Degussa) to evaluate in vivo biodistribution of $\mathrm{TiO}_{2}$ NPs, with particular emphasis on in vivo interactions with the $\mathrm{BBB}$. We evaluated the biokinetics of $\mathrm{TiO}_{2}$ NPs from 5 min up to one year after IV administration to adult Fischer rats at a dose of $1 \mathrm{mg} / \mathrm{kg}$. This mode of administration and concentration was chosen for comparison to the contradictory literature. Moreover, IV allows clarify the potential brain translocation under conditions of $100 \%$ systemic bioavailability without impact of NPs transport across other biological barrier that could impact NPs. In addition, the potential effects on $\mathrm{BBB}$ physiology and subsequent induction of neuroinflammation markers were analyzed.

\section{Results and discussions}

\section{Characterization of titanium dioxide nanoparticles}

Morphology and size of $\mathrm{TiO}_{2} \mathrm{NPs}$ in stock suspensions were determined by Transmission Electron Microscopy (TEM). The mean diameter of individual particles was found to be $21.5 \pm 7.2 \mathrm{~nm}$ (400 counts) (Fig. 1a). Scanning Electron Microscopy (SEM) confirmed spherical morphology of particles and Energy Dispersive X-ray (EDX) analysis on the same images confirmed purity of the product (i.e. only $\mathrm{Ti}$ and $\mathrm{O}$ are detected indicating the absence of other metal contamination greater than $1 \%$ ) (Data not shown). Analysis by X-ray diffraction confirmed the presence of a mixture of $75 \%$ anatase and $25 \%$ rutile crystal phases (Data not shown). The specific surface area, $51 \mathrm{~m}^{2} / \mathrm{g}$, was measured by Brunauer-Emmett-Teller (BET) method and corresponds to $30 \mathrm{~nm}$ grain diameter.

Dynamic light scattering (DLS) measurements shows that NPs agglomerate in water and to a larger extent in saline buffer with hydrodynamic diameters of $163.5 \pm$ 12.6 and $520.9 \pm 41.7 \mathrm{~nm}$, respectively (Fig. 1b). Those measurements highlight the important tendency of $\mathrm{TiO}_{2}$ NPs to aggregate/agglomerate as soon as they are in suspension. We choose not to apply other dispersion protocol for in vivo experiments as they usually necessitate modifying NPs surface. In addition, the size distribution we obtained is comparable to the one in Fabian, Xie and Geraets's study $[15,17,18]$ which would ease data confrontation. Indeed, it is worth noticing that even agglomerated in suspension, NPs form presents a greater 

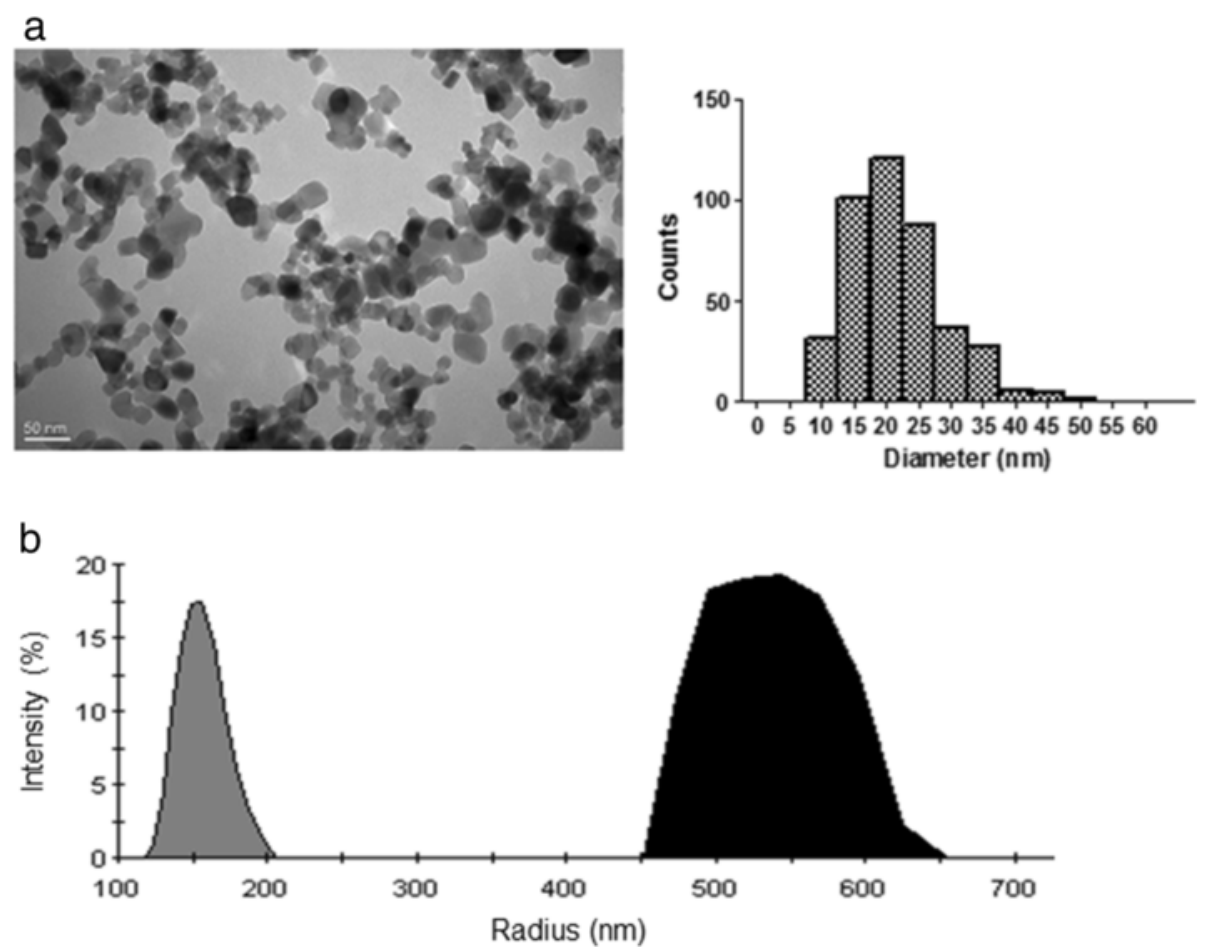

Fig. 1 Characterization of $\mathrm{TiO}_{2} \mathrm{NPs}$. a Representative TEM image of the $\mathrm{TiO}_{2} \mathrm{NPs}$ (magnification $40.000 \mathrm{x}$ ) and size distribution histogram. More than $400 \mathrm{NPs}$ were measured randomly on several micrographs. The average diameter was $21.5 \mathrm{~nm}$ and the standard deviation 7.2. b Size distribution by intensity obtained by DLS for $\mathrm{TiO}_{2}$ NPs suspended in water (grey) or in saline buffer (black). Vigorous vortexing was the only treatment of the suspensions and measurement conditions were optimized resulting in a fixed lens position at $4.65 \mathrm{~mm}$ and a concentration of $25 \mu \mathrm{g} / \mathrm{mL}$. Mean hydrodynamic radius were $163.5 \pm 12.6$ and $520.9 \pm 41.7 \mathrm{~nm}$ for water and saline buffer respectively

reactive surface area that may promote adverse effect compare with the same material particles in micro size scale.

\section{Biodistribution and accumulation studies of titanium dioxide nanoparticles}

Ti burdens in organs and tissues after IV administration are shown in Fig. 2. In a previous work, we fully compared four commonly used mineralization methods for $\mathrm{TiO}_{2}$ NPs and established that one of them involving nitric and hydrofluoric acids, combined to the inductively coupled plasma mass spectrometry (ICP-MS) method allows Ti quantification for NPs in biological samples with limit of quantification (LOQ) from 4.7 to $33.1 \mathrm{ng} / \mathrm{g}$ depending on the tissue sample mass available. This method was validated for linearity, repeatability and accuracy. Matrix effects and recoveries were checked and quantification limit was determined, sine qua none conditions for providing valuable data (Devoy et al., 2015 accepted paper). Ti burdens in liver, spleen and lungs of the treated group were significantly higher than those of the control group from $30 \mathrm{~min}$ to 356 days $(\mathrm{P}<0.001)$. The Ti level was higher in the liver than in spleen and lungs. Assays performed one year after $\mathrm{TiO}_{2} \mathrm{NPs}$ administration to rats indicated that $\mathrm{Ti}$ burden remained high, suggesting longterm biopersistence and no major elimination from the liver. Indeed, approximately $33 \%$ of the $\mathrm{Ti}$ burden at early time points (less than $24 \mathrm{~h}$ ) remain in the liver one year after IV administration. The Ti burden in kidneys of the treated group was significantly higher from $30 \mathrm{~min}$ to $24 \mathrm{~h}$, and then decreased significantly after 7 days after IV administration. Significant levels of $\mathrm{Ti}$ were never found in blood (plasma or blood cells) of the treated group, even at early end point (i.e. $5 \mathrm{~min}$ ).

Our findings confirm previous studies showing that the liver, spleen and lungs appear to be the major organs of accumulation of $\mathrm{TiO}_{2}$ NPs after IV administration $[15-18,28]$ in rodents. We estimate that we recover approximately $44 \%$ of the administered dose in the liver, $10 \%$ in lungs and $2 \%$ in spleen $6 \mathrm{~h}$ after IV administration. As reported previously, the clearance of $\mathrm{TiO}_{2} \mathrm{NPs}$ from the blood circulation is rapid, so $\mathrm{Ti}$ was never detected in plasma or blood cells $[15,28]$. The limit of quantification of the ICP-MS method used is about $15 \mathrm{ng} / \mathrm{ml}$ for plasma and about $14 \mathrm{ng} / \mathrm{g}$ for blood cells. 


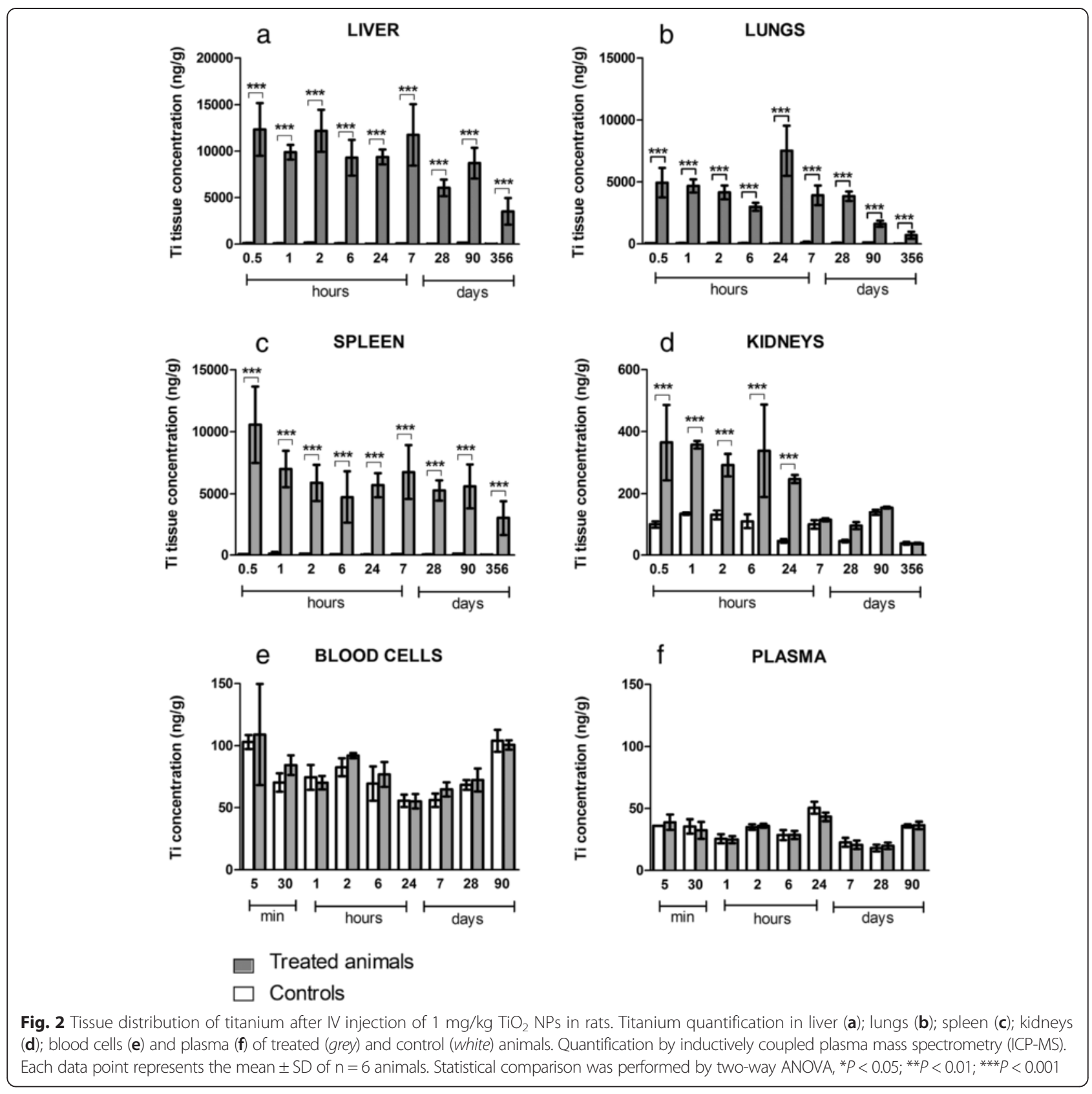

In this context a low blood concentration of Ti cannot be ruled out. Driven by the quantification method developed, we then focused on the Ti brain content.

\section{Quantification of titanium dioxide in the brain}

IV administration of $\mathrm{TiO}_{2} \mathrm{NPs}$ to rats resulted in trace amount of Ti content in total brain at early end points (Fig. 3). Ti was significantly detected from 5 min (brain $\mathrm{Ti}$ concentration was $261.40 \pm 28.86 \mathrm{ng} /$ $\mathrm{g}$ for the treated group vs. $68.25 \pm 6.56 \mathrm{ng} / \mathrm{g}$ for the control group, $P<0.001$ ) to $6 \mathrm{~h}$ (brain Ti concentration was $110.00 \pm 25.05 \mathrm{ng} / \mathrm{g}$ for the treated group vs.
$66.75 \pm 7.36 \mathrm{ng} / \mathrm{g}$ for the control group, $\mathrm{P}<0.001$ ) (Fig. 3a). We found a significant decrease in the cerebral tissue $\mathrm{Ti}$ concentration after $24 \mathrm{~h}$. Ti content after $24 \mathrm{~h}$ in the treated group did not differ significantly from that in the control group. These data are in agreement with the recent study by Geraets et al., who found $\mathrm{Ti}$ in rat total brain $24 \mathrm{~h}$ after IV administration of $5 \mathrm{mg} / \mathrm{kg}$ doses of different $\mathrm{TiO}_{2} \mathrm{NPs}$ whatever their sizes and crystallinity [18]. Shinohara et al. also measured traces of $\mathrm{Ti}$ in rat total brain $6 \mathrm{~h}$ after IV administration of a $0.95 \mathrm{mg} / \mathrm{kg}$ dose of P25 Degussa $\mathrm{TiO}_{2}$ NPs [16]. Fabian et al. did not detect 


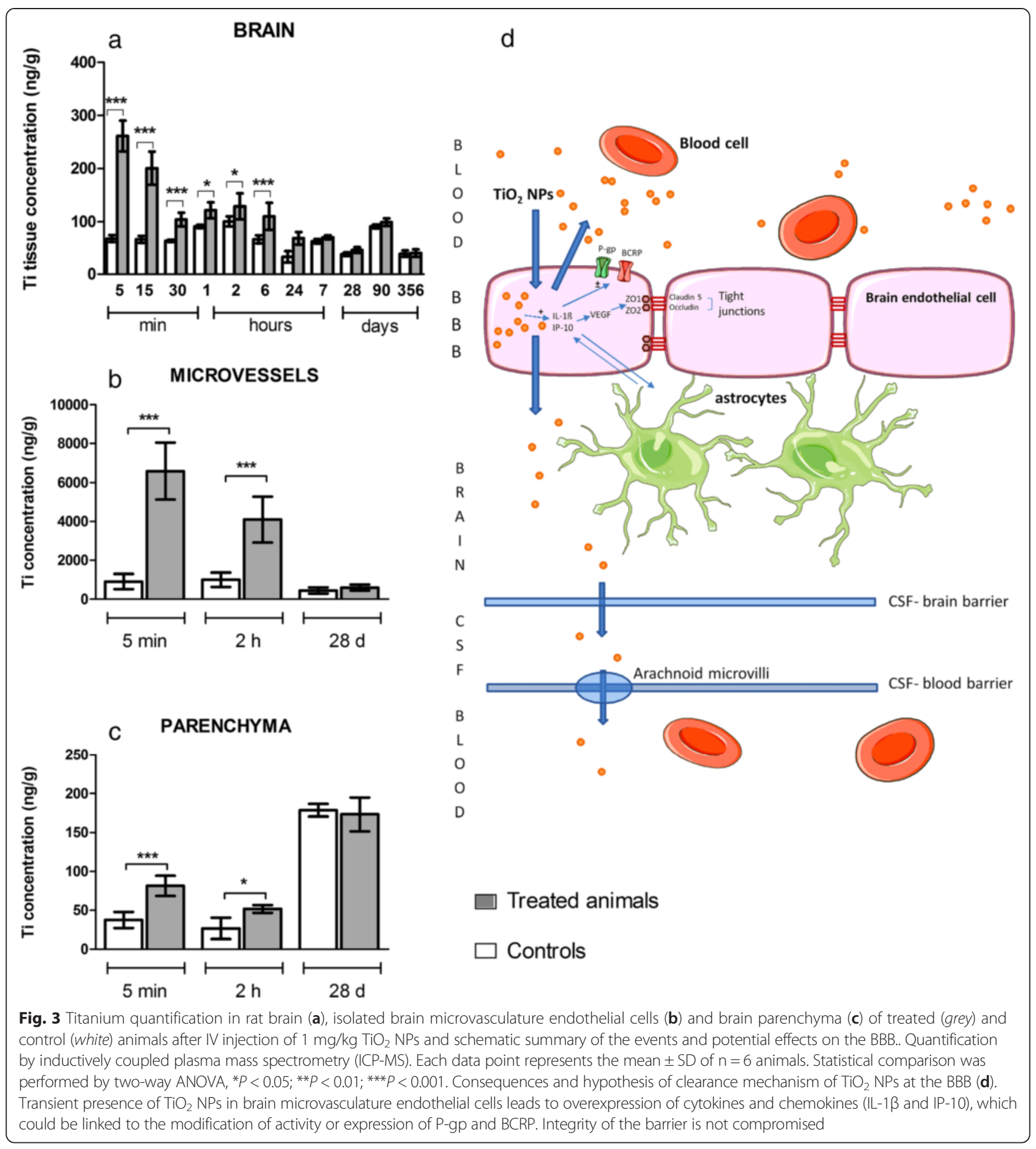

$\mathrm{Ti}$ in the total brain, a result which could be explained by the sensitivity of the analytical inductively coupled plasma atomic emission spectroscopy (ICPAES) method used.

These observations raise one important question: do $\mathrm{TiO}_{2}$ NPs cross the BBB and accumulate in the brain parenchyma or remained located in the brain micro vasculature? As a crucial component of the BBB, the BECs and a fraction corresponding to glial and neural cells referred to as the parenchyma fraction were separated, as we described previously [29]. The purity of the resulting BECs was checked after RNA isolation and real-time PCR experiments by measuring the expression of cellspecific marker genes for BECs (CD31 or PECAM) and for glial cells (glial fibrillary acid protein). The purity of isolated BECs was $99.58 \pm 0.11 \%$ and of the parenchyma 
fraction $98.52 \pm 1.17 \%$. Analysis of Ti content in these two separated fractions highlighted rapid internalization of $\mathrm{TiO}_{2}$ NPs into BECs (at 5 min after IV Ti concentration in treated group was $6579.33 \pm 594.36 \mathrm{ng} / \mathrm{g}$ vs $907.16 \pm 158.70 \mathrm{ng} / \mathrm{g}$ in the control group $P<0.001$ ), followed by a significant decrease at $2 \mathrm{~h}$ (Fig. 3b). With caution to the background increased in the untreated animals at 28 days, at $5 \mathrm{~min}$ and $2 \mathrm{~h}$ after IV a significant increase of Ti between controls and treated animals was found in the parenchyma fraction but correspond to a very low amount of Ti (Fig. 3c). At 28 days after IV administration, $\mathrm{Ti}$ content in BECs was not different in the control and treated groups as well as in the parenchyma fraction of both same age groups. Notwithstanding the uptake of $\mathrm{TiO}_{2}$ NPs by the BECs and the very low concentration found in brain parenchyma, our findings suggest that the $\mathrm{BBB}$ regulates the uptake and clearance of $\mathrm{TiO}_{2}$ NPs. This is in line with previous in vitro findings from our laboratory that have demonstrated rapid internalization of $\mathrm{TiO}_{2}$ NPs by BECs [27] wherein NPs have been evidenced in vesicles, suggesting that isolated or aggregated NPs can be exported from the cell via exocytosis. In vivo, two clearance pathways can be hypothesized: exocytosis back in the blood circulation or transcytosis across BECs to enter the cerebrospinal fluid (Fig. 3d). The mechanism of internalization and clearance of Ti from the BECs thus remain to be determined.

\section{BBB physiology modulations}

Here we have shown that there is early clearance of $\mathrm{TiO}_{2}$ NPs at the BBB and significant biopersistence of $\mathrm{Ti}$ in organs (i.e. liver, spleen, etc.) after IV administration of $\mathrm{TiO}_{2} \mathrm{NPs}$ to rats. This raises the question of whether there is a direct or indirect effect of $\mathrm{TiO}_{2} \mathrm{NPs}$ on $\mathrm{BBB}$ physiology in terms of $\mathrm{BBB}$ integrity, on regulation of proteins involved in brain detoxification, such as P-gp and BCRP, and regulation of neuroinflammation.

\section{$B B B$ integrity}

Since alterations in the expression and/or distribution of tight junction proteins are associated with pathophysiological conditions, such as neurological disorders (Alzheimer disease, multiple sclerosis, dementia, epilepsy, etc.) [10, 30-32], we investigated whether the presence or lack of $\mathrm{TiO}_{2}$ NPs in the BECs after IV administration to rats would compromises BBB integrity or not. Occludin and claudins are key proteins in tight junctions that seal neighboring BECs and limit paracellular diffusion of substances. The expression of claudin- 5 and occludin mRNA was determined, as well as the partition coefficient or Kp of atenolol, a known paracellular drug marker [33], which does not cross the BBB in normal physiological condition. The marketed increase of atenolol $\mathrm{Kp}$ will reflect the increased in the apparent permeability of atenolol attributed to the BBB disruption.

The expression profiles of the genes encoding claudin- 5 and occludin are represented in Fig. 4. In freshly isolated BECs, their mRNA expression levels were not significantly different between control and treated animals at $24 \mathrm{~h}$ after IV administration of $\mathrm{TiO}_{2}$ NPs (Fig. 4a and c). However, notwithstanding the lack of $\mathrm{Ti}$ within the brain, the biopersistence of $\mathrm{Ti}$ in the other organs revealed an increase of claudin-5 and a slight increase for occludin mRNA expression $(P=0.057)$ in the BECs 28 days after IV administration of $\mathrm{TiO}_{2}$ NPs (Fig. 4b and d). The upregulation of tight junction mRNA in BECs correlates with protein expression evidenced by immunofluorescence staining (Figs. 5 and 6). In addition, the brain to plasma concentration ratio $(\mathrm{Kp})$ of atenolol was determined. The atenolol $\mathrm{Kp}$ between controls and treated animals remained unchanged (Fig. 7), suggesting lack of $\mathrm{BBB}$ breakdown after administration of $1 \mathrm{mg} / \mathrm{kg} \mathrm{TiO}_{2} \mathrm{NPs}$ in rats. However, higher doses of $\mathrm{TiO}_{2}$ NPs $(10 \mathrm{mg} / \mathrm{kg})$ induced an increase of atenolol $\mathrm{Kp} 6 \mathrm{~h}$ after IV administration, suggesting compromise of $\mathrm{BBB}$ integrity and testifying for the ability of the integrity probe (Additional file 1). These findings on the consequences of exposing the $\mathrm{BBB}$ to $\mathrm{TiO}_{2} \mathrm{NPs}$ are in accordance with observations on the in vitro $\mathrm{BBB}$ model (Additional file 2).

Overall, these data suggest BECs activation at 28 days and a plausible establishment of a BBB repair mechanism after IV administration of $\mathrm{TiO}_{2} \mathrm{NPs}(1 \mathrm{mg} / \mathrm{kg})$. This raises the question of the mediators potentially involved in these processes.

\section{Regulation of P-gp and BCRP at the $B B B$}

A number of transport and carrier systems are expressed and polarized on the luminal or abluminal surface of the BECs. Among these systems, Adenosine triphosphateBinding Cassette $(\mathrm{ABC})$ transporters play a critical role in preventing neurotoxic substances from entering the brain, and in transporting toxic metabolites out of the brain. mRNA expressions as well as transport activities of two major ABC transporters (Abcb1/P-gp and Abcg2/ $\mathrm{BCRP})$ at the $\mathrm{BBB}$ were investigated after IV administration of $\mathrm{TiO}_{2}$ NPs. Data depicted in Fig. 8a and c show no change in $A b c b 1$ and $A b c g 2$ mRNAs at $24 \mathrm{~h}$ in the rat BECs, while biopersistence of $\mathrm{Ti}$ in organs except brain (28 days) correlated with an increase in $A b c b 1$ mRNAs but not $A b c g 2$ mRNAs expression (Fig. 8b, d), suggesting differential $\mathrm{P}$-gp and BCRP transporter regulation mechanisms. The regulation of $A b c b 1$ mRNAs has been also described in the context of oxidative stress, signaling initiated by Diesel Exhaust Particles for 


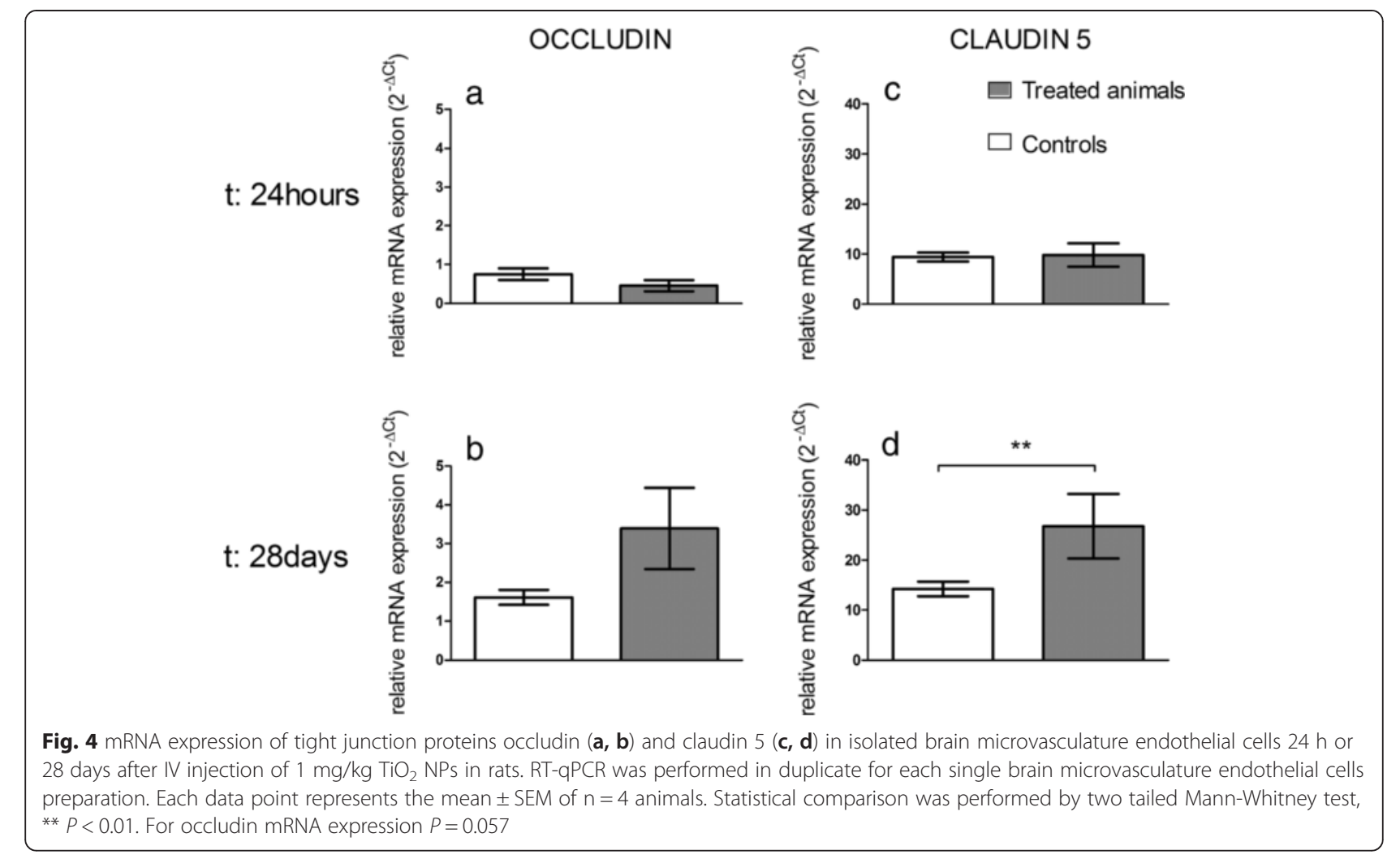

example, due to the activation of Nicotinamide Adenine Dinucleotide Phosphate-oxidase which produces Reactive Oxygen Species, stimulates Tumor Necrosis Factor $-\alpha$ $(\mathrm{TNF}-\alpha)$ release and activate TNF receptor 1 (TNF-R1). In turn, TNF-R1 activates the transcription factor Activator Protein 1 leading to an increase in P-gp expression. Activation of nuclear factor E2-related factor-2, a sensor of oxidative stress, also upregulates P-gp expression at the $\mathrm{BBB}$ [34]. To determine whether the increase in mRNA expressions resulted in changes in protein activity, we measured the Kp of digoxin and prazosin as examples of P-gp and BCRP substrates [35-39], respectively. A decrease of transporter activity is indicated by his substrate Kp increase. Functional studies show a rapid down regulation of BCRP activity indicated by a brain increase of prazosin concentration $6 \mathrm{~h}$ after exposure to $\mathrm{TiO}_{2}$ NPs $\left(K \mathrm{p}_{\text {prazosin }}=0.48 \pm 0.03\right.$ for treated group versus $K \mathrm{p}_{\text {prazosin }}=0.34 \pm 0.03$ for control group), whereas no change in transport activity was observed at $24 \mathrm{~h}, 7$ or 28 days after $\mathrm{TiO}_{2}$ NP exposure (Fig. 8e). These findings pointed out different signaling processes at the BBB level during early (e.g. direct interaction of $\mathrm{TiO}_{2}$ NPs with the BBB) and late events (e.g. cytokine signaling) after IV $\mathrm{TiO}_{2}$ NPs administration to animals. Such regulation has been evidenced when brain capillaries was exposed to low levels of Lipopolysaccharide [34, 40]. We could not correlate the increase in $A b c b 1$ mRNA expressions 28 days with the P-gp protein transport activity since brain digoxin concentrations were under the quantification limit in both the controls and the treated group, so P-gp activity was not measurable. It is worth noticing that this disturbance of P-gp and BCRP expression or activity was also observed on the in vitro cell based BBB model after $24 \mathrm{~h}$ exposure to $\mathrm{TiO}_{2} \mathrm{NPs}$ (data not shown). Such disturbance of BCRP or P-gp activities could alter the detoxification function of the BBB. Indeed, P-gp and BCRP have a very wide variety of substrates and modulation of their efflux capacities even low can potentially lead to accumulation of neurotoxics in the brain parenchyma [41].

\section{Neuroinflammation assessment and relation to biopersistence of $\mathrm{TiO}_{2} \mathrm{NPs}$ in organs}

Finally, we were concerned about a potential neuroinflammation as such a phenomenon was at stage in our in vitro cell based $\mathrm{BBB}$ model and described in vivo after intraperitoneal injection of $\mathrm{TiO}_{2} \mathrm{NPs}[22,42]$. We studied the influence of the short-term presence of $\mathrm{Ti}$ in the BECs and the impact of biopersistence of $\mathrm{Ti}$ in other organs on CNS inflammation, especially at the BBB and in the brain parenchyma. The presence of $\mathrm{Ti}$ in BECs at early end point depicted in Fig. 3b (significant up to $24 \mathrm{~h}$ after IV administration) is correlated with a significant increases of interleukin $1 \beta$ (IL-1 $\beta$ ) and chemokine ligand 1 (CXCL1) (Fig. 9). These increases in addition to 

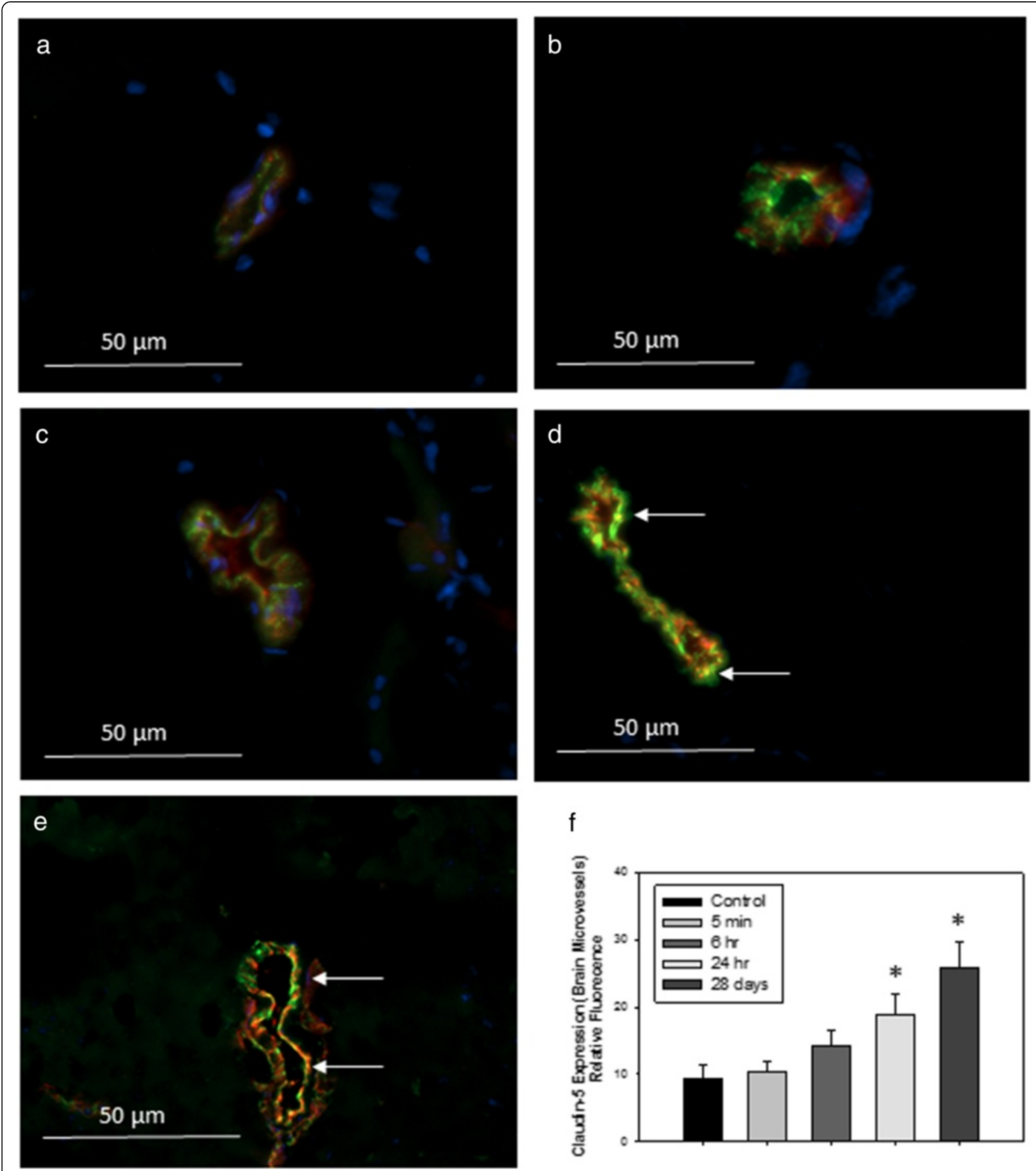

Fig. 5 Representative images of immunofluorescence expression of tight junction protein claudin-5 (red) and endothelial cell marker vonWillebrand factor (VWF, green) in the cerebral microvasculature of (a) control rats, or tissues collected from rats treated with $1 \mathrm{mg} / \mathrm{kg} \mathrm{TiO}_{2}$ (IV) at (b) $5 \mathrm{~min}$; (c) $6 \mathrm{~h}$; (d) $24 \mathrm{~h}$ or (e) 28 days post-treatment. Yellow fluorescence indicates overlay (co-localization) of claudin-5 and vWF. Arrows indicate areas of increased yellow fluorescence. Graph in (f) shows analysis of relative fluorescence of overlay images $\pm S D$. ${ }^{*} P<0.050$ compared to controls

$\gamma$ inducible protein-10 (IP-10/CXCL10) are maintained 28 days after IV administration, whereas no Ti was detected in BECs or in the brain parenchyma. In the brain parenchyma, we also noted an increase of interleukin 6
(IL6) expressions at 28 days after IV administration (Fig. 9). First, the persistent brain inflammation evidenced in this study at the brain microvasculature level 28 days after $\mathrm{TiO}_{2}$ NPs exposure raised the question of 

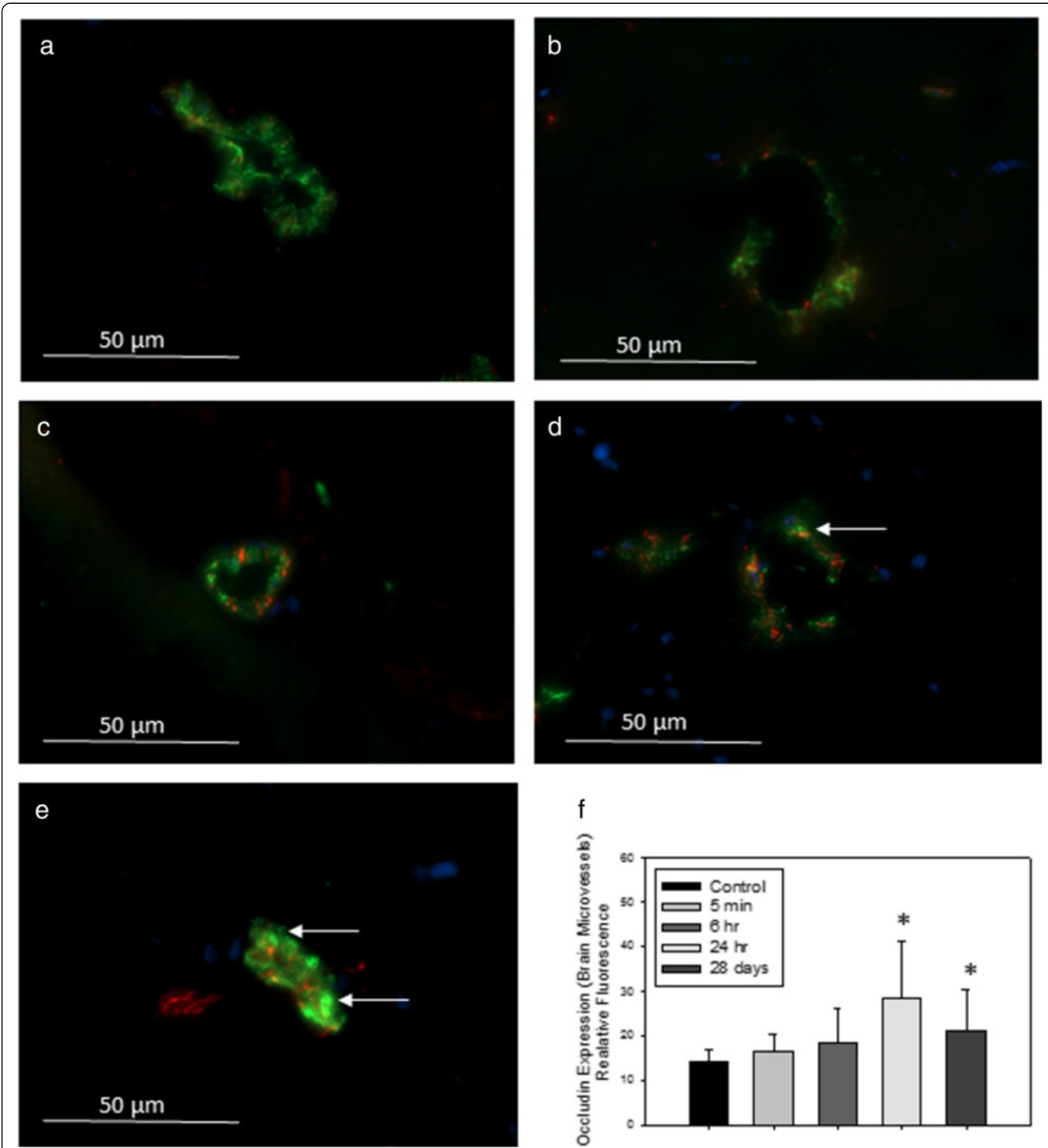

Fig. 6 2Representative images of immunofluorescence expression of tight junction protein occludin (red) and endothelial cell marker vonWillenbrand factor (VWF, green) in the cerebral microvasculature of (a) control rats, or tissues collected from rats treated with $1 \mathrm{mg} / \mathrm{kg} \mathrm{TiO}_{2}$ (IV) at (b) $5 \mathrm{~min}$; (c) 6 h; (d) 24 h; or (e) 28 days post-treatment. Yellow fluorescence indicates overlay (co-localization) of occludin and vWF. Arrows indicate areas of increased yellow fluorescence. Graph in (f) shows analysis of relative fluorescence of overlay images \pm SD. ${ }^{*} P<0.050$ compared to controls

potential brain dysfunction. Indeed, a link between persistent neuro-inflammation and brain pathologies as already been established [43]. Second, modifications of P-gp and structural tight junction protein mRNA expressions come with modulation of cytokines and chemokines 28 days after $\mathrm{TiO}_{2} \mathrm{NPs}$ administration to rats. This is not correlated with measurable Ti brain and plasma content. In this context, an indirect mechanism of interactions between NPs and BECs could be suggested. It is likely that soluble mediators interacts with 


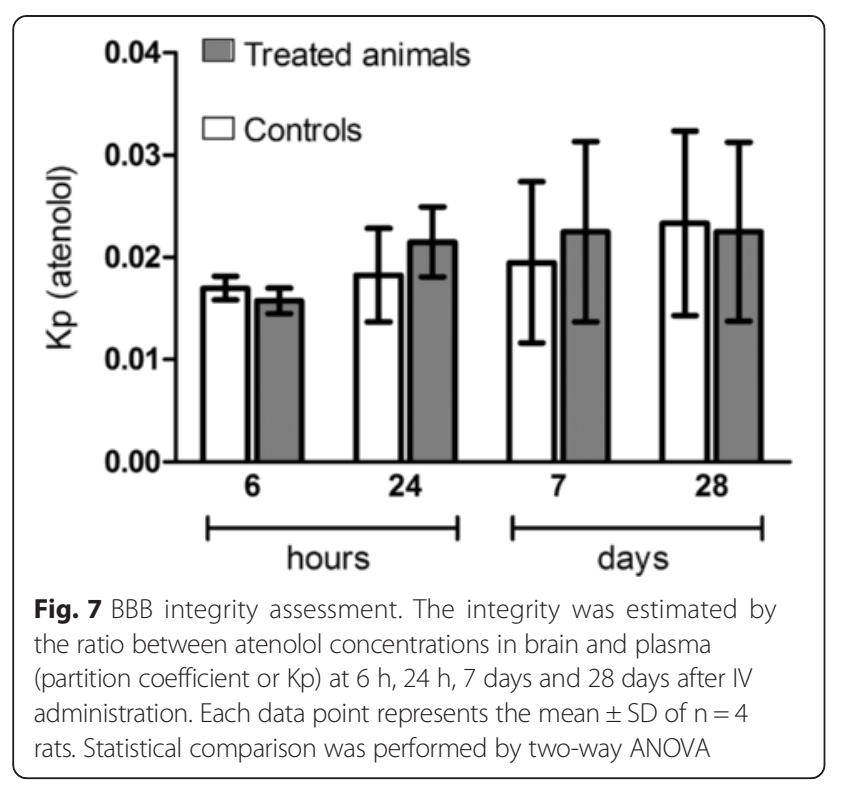

their BBB targets and elicit BECs activation and neurovascular inflammation. For example, pro-inflammatory mediators such as TNFo distributed through the systemic circulation affect $\mathrm{ABC}$ transporter expression and activity [44, 45]. We thus suggest that 28 days after exposure, circulating cytokines and chemokines released probably by organs containing high amounts of $\mathrm{Ti}$ induce activation of BECs and initiate the release of IL- $1 \beta$, IP-10 and CXCL1, which act in a paracrine way to activate astrocytes/microglia cells in the brain parenchyma. Immunofluorescence staining revealed an increase of IL$1 \beta$ in the rostral and caudal diencephalon (Fig. 10). Because of its massive and biopersistence of $\mathrm{Ti}$, liver could be a key organ for induction of oxidative stress, lipid composition modifications, and immune response as reported elsewhere [25, 46-48]. Mediators such as cytokines, chemokines and lipids circulating in the blood may be responsible indirectly for BBB deregulation at late end points. Transposition of the effect evidenced at the $\mathrm{BBB}$ on other endothelial cells by blood circulating factors could not be excluded.

\section{Circulating serum factors from rats treated with $\mathrm{TiO}_{2} \mathrm{NPs}$ induce an inflammatory response in a cell-based BBB model}

To demonstrate whether circulating cytokines/mediators that may be released by organs bioaccumulating Ti can lead to neurovascular inflammation and BBB physiology alterations, we performed in vitro studies on the primary rat cell-based BBB model described previously [26]. The model was exposed to diluted sera from untreated and treated animals collected 28 days after exposure to $\mathrm{TiO}_{2}$ NPs. Exposure of the apical compartment mimics bloodborne exposure. After $24 \mathrm{~h}$ of exposure to serum, the integrity of the BECs monolayer was checked and BECs and glial cells were recovered for mRNA profiling.

After $24 \mathrm{~h}$ of exposure, the integrity of the BECs monolayer remained intact in the control group as well as in the treated group (Fig. 11f), thus confirming the maintenance of $\mathrm{BBB}$ integrity observed 28 days after exposure in vivo (apparent permeability $\left(\mathrm{P}_{\text {app }}\right)$ for Lucifer Yellow (LY) was $2.08 \pm 0.99 \mathrm{~cm} / \mathrm{s}$ for controls vs $2.17 \pm 0.77 \mathrm{~cm} / \mathrm{s}$ for the treated group). In BECs, we noted a tendency of increase for occludin mRNA expression $(P=0.057)$, which is in accordance with in vivo observations. The mRNA expressions of IL6, CXCL1 and glial fibrillary acid protein (GFAP) in astrocytes were upregulated. These inflammatory markers are key proteins for communication between glial and BECs [49-54]. This in vitro mRNA upregulation in glial cells of the BBB model suggests that the mediators are present 28 days after exposure in the serum of treated rats and allows to consolidate our hypothesis of circulating mediators.

\section{Conclusions}

The major findings of our study are depicted in Fig. 12 and Fig. 3d. They show a Ti burden in the liver, spleen and lungs up to 356 days after IV administration of $\mathrm{TiO}_{2} \mathrm{NPs}$ to rats, with very low clearance rate observed until one year after administration. Additionally, we describe for the first time the in vivo uptake and clearance by $\mathrm{BECs}$ of $\mathrm{TiO}_{2} \mathrm{NPs}$ after exposure. Furthermore, this is the first study reporting the link between deregulation of BBB physiology and the presence of $\mathrm{TiO}_{2} \mathrm{NPs}$ in distal organs. Upregulation of tight junction proteins, modulation of P-gp mRNA expression and persistent brain inflammation markers such as IL-1 $\beta$, IP-10 and CXCL1 were highlighted. Thus, regardless of where the peripheral signal originates from, our findings raise the question of circulating biomarkers potentially released by organs accumulating $\mathrm{Ti}$ to promote dysregulation of BBB physiology and neuroinflammation. Substantial research remains to be done to identify such peripheral biomarkers. Our findings point out for the first time that $\mathrm{TiO}_{2} \mathrm{NPs}$ can exert indirect effect on the CNS that seems dependent on the circulation.

\section{Materials and methods \\ Chemicals}

Human serum, bovine serum albumin (BSA), N-alphatosyl-L-lysinyl-chloromethylketone (TLCK) and Lucifer yellow (LY), Digoxin, Prazosin, Atenolol and Atenolold7 were from Sigma Aldrich (Saint-Quentin Fallavier, France). Collagenase/dispase and DNAse I were from Roche Applied Science (Basel, Switzerland). Digoxien-d3 was from Artmolecule (Poitier, France).

All chemicals used for ICP-MS were of analytical grade. Nitric acid was used to prepare $0.2 \% \mathrm{HNO}_{3}(v / v)$ with ultrapure water. All single element stock solutions 


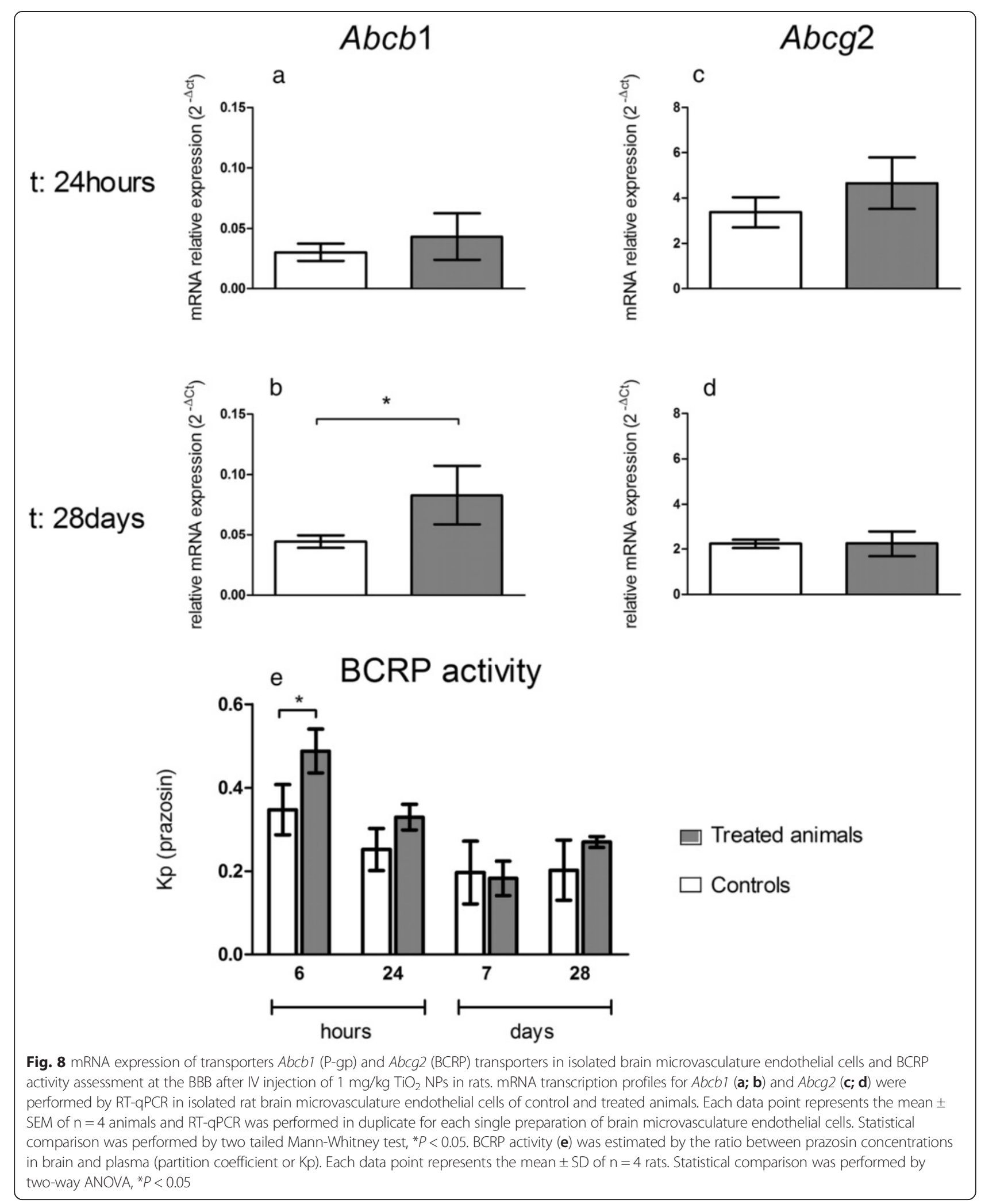

(1000 mg/L) were delivered by SCP Science and certified for purity and concentration. From these stock solutions, a mixed working standard solution with a concentration of $10 \mathrm{mg} / \mathrm{L}$ for each element was prepared by putting $1 \mathrm{~mL}$ of each stock solution in a $100 \mathrm{~mL}$ measuring flask, adding $5 \mathrm{~mL}$ of purified 


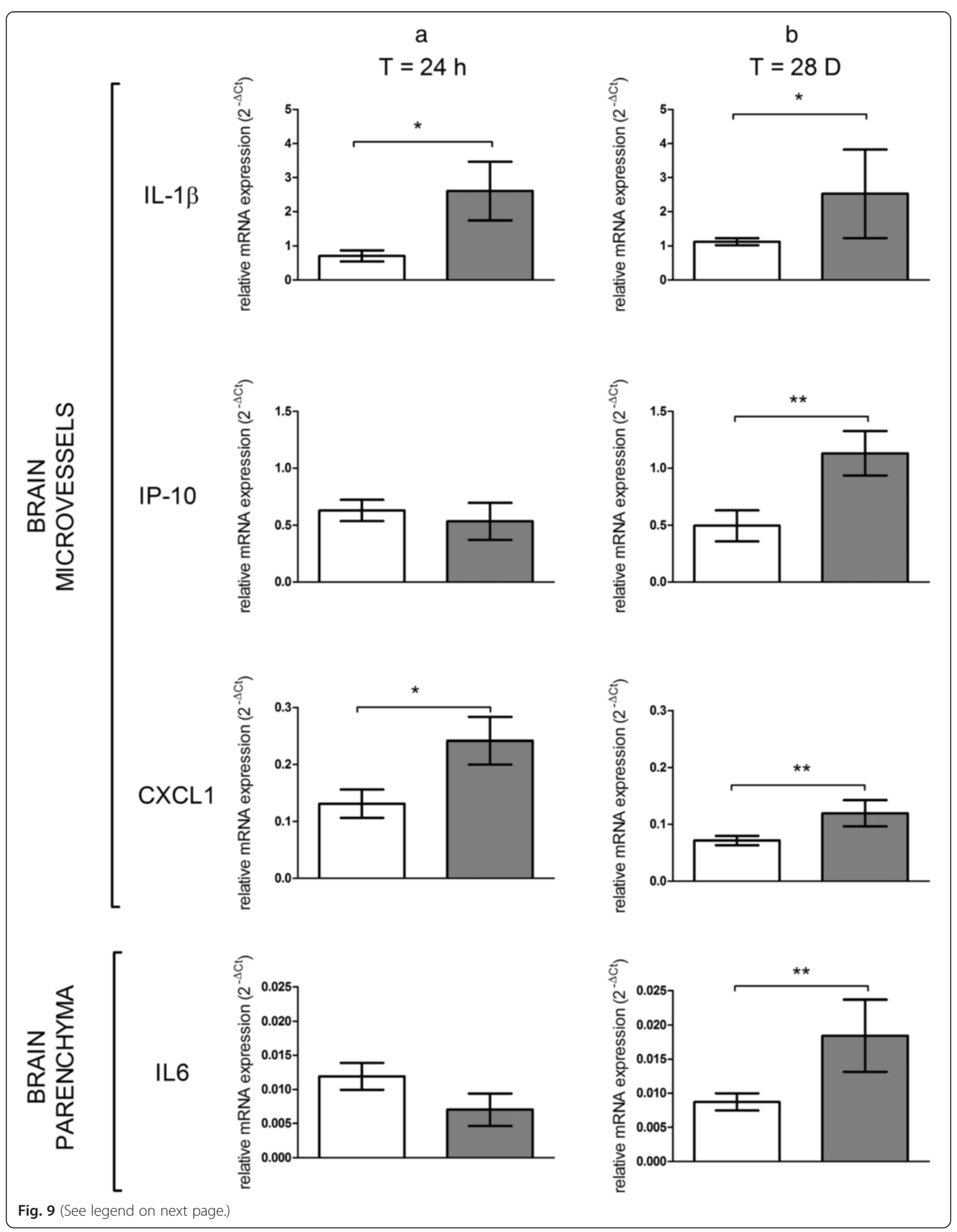


(See figure on previous page.)

Fig. 9 mRNA expression of cytokines and chemokines in isolated brain microvasculature endothelial cells and parenchyma fraction after IV injection of $1 \mathrm{mg} / \mathrm{kg} \mathrm{TiO}_{2}$ NPs in rats. mRNA transcription profiles for IL-1 $\beta$, IP-10 and CXCL1 in isolated rat brain microvasculature endothelial cells and IL6 in parenchyma fractions of control and treated animals performed by RT-qPCR at $24 \mathrm{~h}$ (a) and 28 days (b) after IV injection. Each data point represents the mean \pm SEM of $n=4$ animals and RT-qPCR were performed in duplicate for each single preparation of brain microvasculature endothelial cells. Statistical comparison was performed by one tailed Mann Whitney test, ${ }^{*} P<0.05$; ${ }^{* *} P<0.01$

$\mathrm{HNO}_{3}$ and diluting to $100 \mathrm{~mL}$ with ultrapure water (MilliQ, Millipore, Germany).

\section{$\mathrm{TiO}_{2}$ nanoparticles}

$\mathrm{TiO}_{2} \mathrm{P} 25$ NPs (Aeroxide ${ }^{\circ} \mathrm{P} 25,75 \%$ anatase $25 \%$ rutile, Evonik $^{\circ}$ ) were from Sigma Aldrich (Saint-Quentin Fallavier, France). For in vivo experiments, $\mathrm{TiO}_{2} \mathrm{NPs}$ were suspended in sterile physiological salt solution at a stock concentration of $1 \mathrm{mg} / \mathrm{mL}$. No other treatment was performed. A thorough characterization of NPs was conducted through a panel of complementary techniques. NPs were imaged by Transmission Electron Microscopy (TEM) with a JEOL 1400 instrument (JEOL, Tokyo, Japan) operating at $80 \mathrm{keV}$ (Imagif platform, Gif-surYvette) and Scanning Electron Microscopy (SEM) (Carl Zeiss, Ultra 55) equipped with an Energy Dispersive Xray spectrometer (EDX) allowing elemental analysis. For both TEM and SEM analyses, samples were prepared as follows: $3 \mu \mathrm{L}$ droplet of the dispersion was cast on formvar/ carbon-coated copper grids for $5 \mathrm{~min}$. The Brunauer-Emmett-Teller (BET) method (Micromeritics FlowsorbII 2300) was applied to determine the specific surface area (SSA) of the nanopowder and diameter was calculated from the SSA value, as $\mathrm{D}=6000 /(\rho . S S A)$, where D is BET diameter $(\mathrm{nm})$, and $\rho=3.9 \mathrm{~g} \cdot \mathrm{cm}^{-3}$ is the density of anatase $\mathrm{TiO}_{2}$. The crystalline phases were measured by X-Ray Diffraction (XRD) with a Siemens D5000 instrument using the $\mathrm{Cu}-\mathrm{K} \alpha$ radiation and using the Match software (crystal impact). Hydrodynamic diameter was measured by Dynamic Light Scattering (DLS) using a ZetaSizer ZEN3600 (Malvern, Herenberg, Germany) equipped with a $633 \mathrm{~nm}$ laser.

\section{Animals and intravenous $\mathrm{TiO}_{2}$ NPs administration protocol}

Male Fisher F344 rats (from Charles River Laboratories, France), 8 weeks old and weight 180-250 g, were housed in standard environmental conditions (room humidity and temperature controlled $19{ }^{\circ} \mathrm{C}-23{ }^{\circ} \mathrm{C}$; room under a 12 : $12 \mathrm{~h}$ light dark cycle) and maintained with free access to water and standard laboratory diet. The control animals were injected intravenously via the tail vein with $1 \mathrm{~mL} / \mathrm{kg}$ of sterile saline buffer and the treated animals were injected with $\mathrm{TiO}_{2} \mathrm{NPs}$ suspension at the dose of $1 \mathrm{mg} / \mathrm{kg}$. $\mathrm{TiO}_{2}$ NPs suspension was vortex for 5 min before administration. No other dispersion protocol was used to avoid false positive results that would be due to inappropriate handling of the dispersion protocol of NPs.

30 min, 1 h, 2 h, 6 h, 24 h, 7 days, 28 days, 90 days or 356 days after IV injection, animals were anesthetized with isoflurane and euthanized. Additional time points at 5 min and 15 min was set up for brain and blood collection. Blood, liver, brain, spleen, kidneys and lungs were collected and stored at $-80{ }^{\circ} \mathrm{C}$ until assayed. All procedures were approved by the CEA Institute's Animal Care and Use Committee and conform to the Guide for the Care and Use of Laboratory Animals published by the European community's council (directives 86/609/EEC, November 24, 1986), and the French directives concerning the use of laboratory animals (February 2013).

\section{Sample Preparation and Ti analysis by ICP-MS}

Tissues from 6 controls and 6 treated rats were used for biodistribution studies. Tissues were thawed and about $0.1-0.3 \mathrm{~g}$ of each tissue was weighed, digested and analyzed for Ti content. Each sample was added to a $55 \mathrm{~mL}$ microwave digestion vessel along with $8 \mathrm{~mL}$ of nitric acid and $2 \mathrm{~mL}$ of hydrofluoric acid and digested using a Microwave Assisted Reaction System (MARS) Express instrument. The microwave digestion program was $15 \mathrm{~min} ; 150{ }^{\circ} \mathrm{C}$; $1200 \mathrm{~W}$ then $15 \mathrm{~min} ; 180{ }^{\circ} \mathrm{C} ; 1200 \mathrm{~W}$ followed by $20 \mathrm{~min}$ cooling. After cooling, the sample was rinsed 3 times using approximately $20 \mathrm{~mL}$ of $2 \%$ nitric acid solution in a polytetrafluoroethylene (PTFE or Teflon) beaker. $2 \mathrm{~mL}$ of hydrogen peroxide was added to each beaker to digest any remaining organic matter. The beaker was then heated on a hot plate at $180{ }^{\circ} \mathrm{C}$ until between 0.1 and $0.5 \mathrm{~mL}$ of solution remained. The beakers were removed from the hot plate, allowed to cool and rinsed 3 times with $2 \%$ nitric acid solution into a $25 \mathrm{~mL}$ volumetric flask before being stored for analysis. Samples were refrigerated at $-20{ }^{\circ} \mathrm{C}$ while not in use.

This digestion method was evaluated for the recovery of a known amount of $\mathrm{TiO}_{2}$ and the ability to digest organic material sufficiently for analysis. The method was applied to a number of blank samples, containing only the reagents and no sample, in order to measure the amount of Ti contamination.

\section{Analysis of Ti with ICP-MS}

Ti standard solutions for ICP-MS calibration were prepared at concentrations of 2, 4, 8, 10, 30, 50 and $100 \mathrm{ng} /$ 

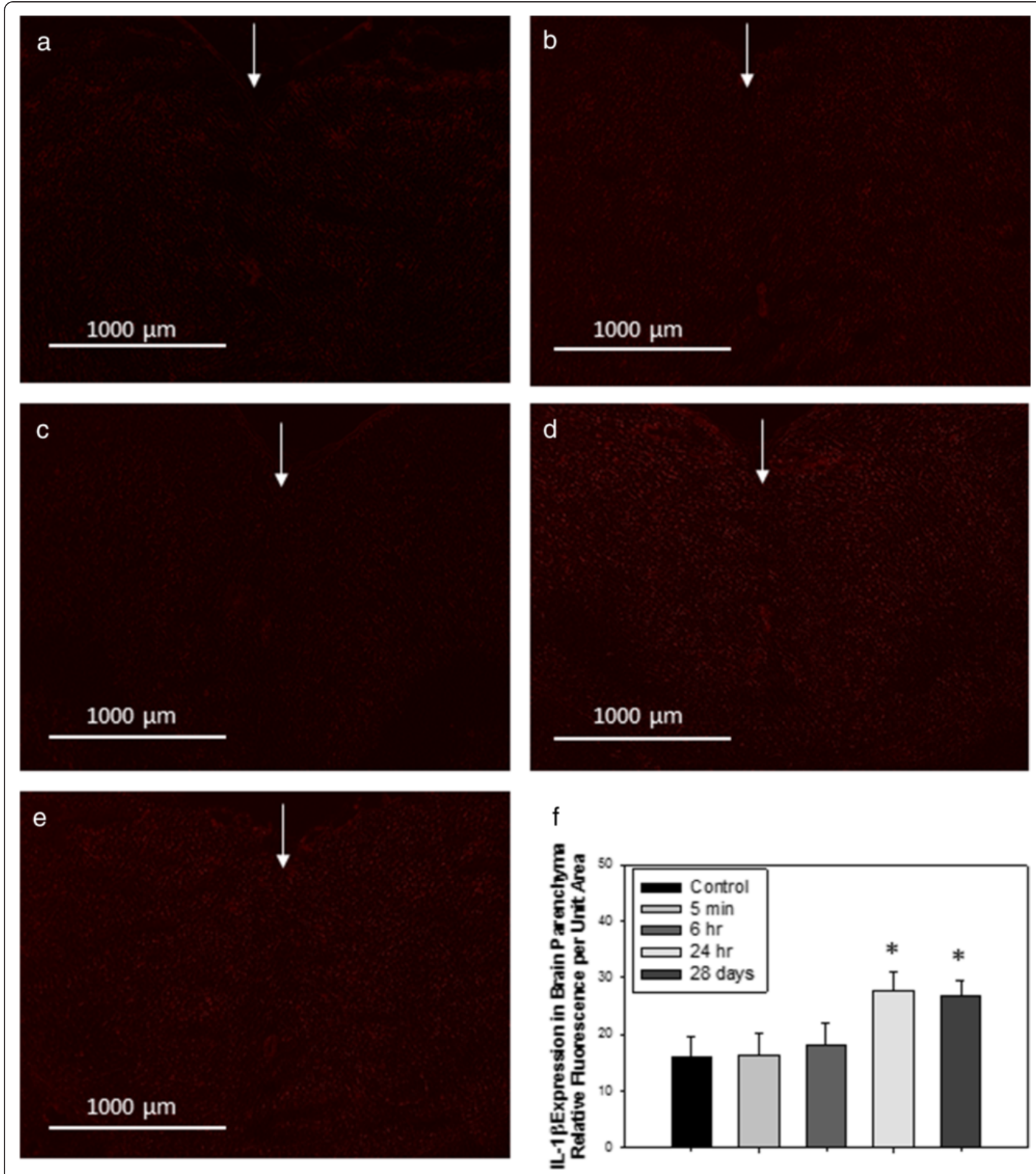

Fig. 10 Representative images of immunofluorescence expression of IL-1ß in the cerebral parenchyma of (a) control rats, or tissues collected from rats treated with $1 \mathrm{mg} / \mathrm{kg} \mathrm{TiO}_{2}(\mathrm{I})$ at (b) $5 \mathrm{~min}$; (c) $6 \mathrm{~h}$; (d) $24 \mathrm{~h}$; or (e) 28 days post-treatment. Arrows indicate sagittal suture (coronal cut, sections cut and analyzed between rostral and caudal diencephalon). Graph in (f) shows analysis of relative fluorescence of overlay images \pm SD. ${ }^{*} P<0.050$ compared to controls

L, by diluting a $1 \mathrm{~g} / \mathrm{L}$ Ti standard stock solution (1.70363.0100, SCP Science) with $2 \% v / v \mathrm{HNO}_{3}$ and $0.01 \% v / v$ Triton X-100. An internal standard solution, containing $25 \mu \mathrm{g} / \mathrm{L}$ of $\mathrm{Ge}$ was prepared by diluting a $1000 \mathrm{mg} / \mathrm{L}$ internal standard stock solution (1.70320.0100, Merck) with $2 \% v / v \mathrm{HNO}_{3}$. The internal standard $(25 \mu \mathrm{g} /$ 


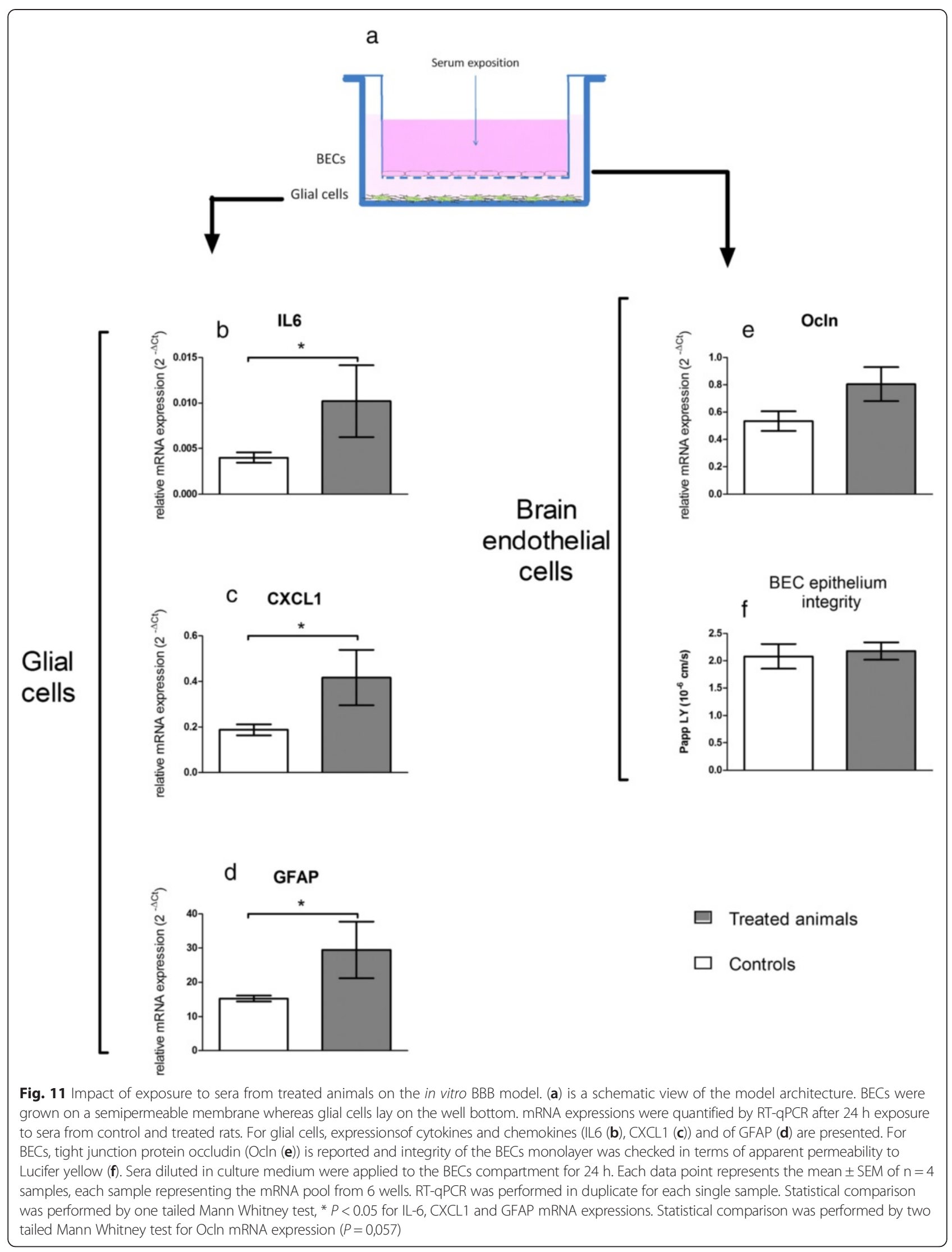




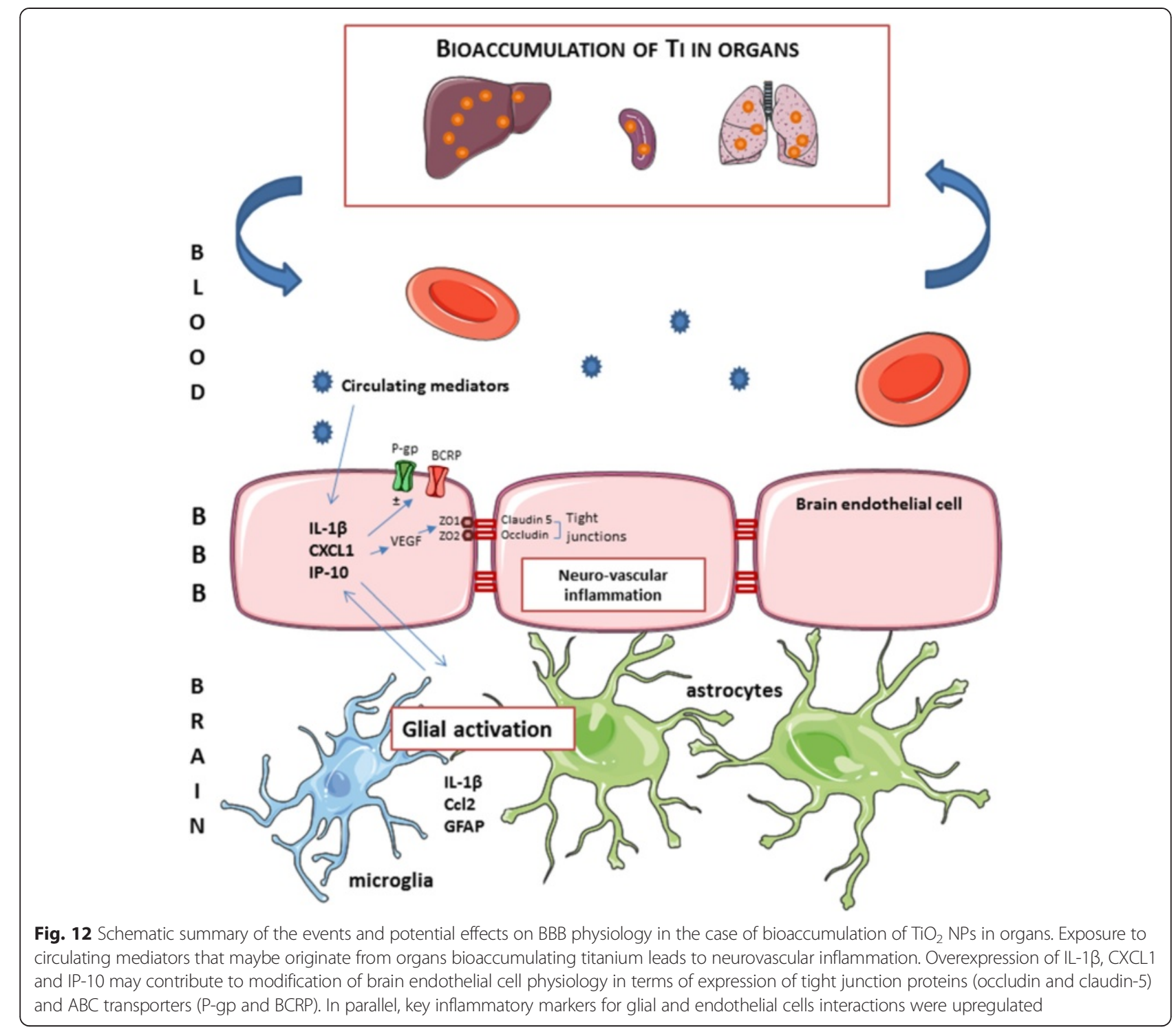

L Ge) was added in all samples and standards. Ti analysis of acidified samples was carried out using a Varian 820MS. Samples in $2 \% v / v \mathrm{HNO}_{3}$ were directly analyzed with the Varian-820-MS for Ti determination.

\section{BBB permeability and P-Glycoprotein and BCRP transport activity measurement}

Four hours before sacrifice, 4 control and 4 treated rats were subcutaneously implanted with mini-osmotic pumps (Alzet model 2001D; DURECT Corp., Cupertino, California). Pumps were filled with atenolol, digoxin and prazosin dissolved in PEG200/DMSO (50/50) to deliver at $0.25 \mathrm{mg} /$ $\mathrm{kg} / \mathrm{h}, 0.5 \mathrm{mg} / \mathrm{kg} / \mathrm{h}$ or $0.25 \mathrm{mg} / \mathrm{kg} / \mathrm{h}$ rates, respectively. The relevance of distribution study of atenolol, digoxin and prazosin in plasma and brain for BBB integrity and transport function assessment was previously demonstrated
[26, 29]. 6 h, 24 h, $7 \mathrm{~d}$ or $28 \mathrm{~d}$ after IV injection, animals were anesthetized with isoflurane and euthanized. Plasma samples and brain were collected and weighed immediately after death. The administered substrates were quantified in the two compartments using mass spectrometry coupled with liquid chromatography (LC/MS). BBB integrity was estimated by the ratio of atenolol brain to plasma concentration $\left(\mathrm{C}_{\text {brain }}\right.$ and $\mathrm{C}_{\text {plasma }}$, respectively). This ratio is described by the partition coefficient $(\mathrm{Kp})$.

$$
K p=\frac{C_{\text {brain }}}{C_{\text {plasma }}}
$$

The P-gp and BCRP transport activities were estimated by means of the digoxin and prazosin Kp, respectively. 


\section{LC/MS assay for digoxin, prazosin and atenolol quantification}

Brains were mixed in ultrapure water $(2 \mathrm{~mL} / \mathrm{g}$ of tissue) using an Ultraturrax T65 system (IKA-Werke, Staufen, Germany). Extract suspensions $(400 \mu \mathrm{L})$ were submitted to protein precipitation with $1 \mathrm{~mL}$ of methanol previously spiked with internal standard (digoxin-d3 and atenolol-d7 $4 \mu \mathrm{g} / \mathrm{mL}$ ). After centrifugation (20000 g; $15 \mathrm{~min} ; 4^{\circ} \mathrm{C}$ ) the supernatant was dried under nitrogen at $40{ }^{\circ} \mathrm{C}$. The dried extracts were resuspended in $1 \mathrm{~mL}$ $0.75 \mathrm{M} \mathrm{NH}_{4} \mathrm{OH} /$ methanol $(80: 20 \nu / v)$. Plasma $(150 \mu \mathrm{L})$ was diluted with $150 \mu \mathrm{L}$ of $0.75 \mathrm{M} \mathrm{NH}_{4} \mathrm{OH} /$ methanol $(80: 20 \mathrm{v} / \mathrm{v})$ previously spiked with internal standard. Both brain and plasma extracts were submitted to solid-liquid extraction on isolute SLE+ columns 1 or $6 \mathrm{~mL}$ (Biotage). The two eluates $(3 \mathrm{~mL}$ of dichloromethane/isopropanol $(70: 30 \mathrm{v} / \mathrm{v})$ then $3 \mathrm{~mL}$ of dichloromethane/isopropanol $(70: 30 v / v)+0.2 \%$ formic acid) were pooled and evaporated to dryness. The dry extracts were resuspend in $200 \mu \mathrm{L}$ of $5 \mathrm{mM}$ ammonium acetate/methanol (95:5 v/ v). Chromatography was performed using a Shimadzu HPLC system LC 20 AD on a Kinetex C18 column (Phenomenex). The total run time was $5 \mathrm{~min}$ and the flow rate was $0.4 \mathrm{~mL} / \mathrm{min}$. Analyte $(20 \mu \mathrm{L})$ was injected onto the column placed in an oven at $40{ }^{\circ} \mathrm{C}$.

Detection was done by tandem mass spectrometry (Finnigan TSQ Quantum Discovery with Xcalibur and LC Quan softwares, Thermo) in positive electrospray mode. Tuning parameters were: capillary voltage $3 \mathrm{kV}$, source temperature $200{ }^{\circ} \mathrm{C}$. The multiple reaction monitoring transitions for analytes were as follows: $\mathrm{m} / \mathrm{z}$ digoxin $798.5>651.4, \mathrm{~m} / \mathrm{z}$ prazosin $384.19>247.14, \mathrm{~m} / \mathrm{z}$ atenolol $267.18>145.1$. Analytes were quantified by means of calibration curves using digoxin-d3 or atenolol-d7 as internal standard. For plasma and brain extract assay, calibration ranges were from 1.0 to $200 \mathrm{ng} / \mathrm{mL}$.

\section{Isolation of brain microvasculature endothelial cells}

Rat brain capillaries were isolated as described previously $[26,55] .6$ rats from three relevant time groups ( $5 \mathrm{~min} ; 2 \mathrm{~h}$ and 28 days) were used. Brains were extracted and stored in Hanks balanced salt solution (HBSS) supplemented with $1 \%(v / v)$ PSN on ice. The remainder of the isolation took place under aseptic conditions. The brains were cut sagittally into two halves and the cerebral cortices emptied of white matter. The meninges and the associated vessels were cleaned off by rolling on Whatman $3 \mathrm{~mm}$ chromatography paper. The homogenized tissue was pelleted by centrifugation at $1500 \mathrm{rpm}$ for $5 \mathrm{~min}$. The pellet containing the microvessels was digested in HBSS-1 \% PSN solution, $1 \mathrm{mg} / \mathrm{mL}$ collagenase/dispase, $10 \mathrm{U} / \mu \mathrm{L}$ DNase-I, and $1 \mu \mathrm{g} / \mathrm{mL}$ TLCK for $1 \mathrm{~h}$ at $37^{\circ} \mathrm{C}$. Digested tissue was then pelleted by centrifugation at $1500 \mathrm{rpm}$ for $5 \mathrm{~min}$ at $4{ }^{\circ} \mathrm{C}$. To remove myelin, the pellet was resuspended in $20 \%(\mathrm{w} / \mathrm{v})$ BSA in HBSS-1 \% PSN solution and centrifuged at $2800 \mathrm{rpm}$ for $30 \mathrm{~min}$. The resulting floating white matter corresponding to the brain parenchyma fraction and centrifugation medium were removed carefully. The microvessel pellets were washed then frozen at $-80{ }^{\circ} \mathrm{C}$. The remaining parenchyma fraction was resuspended in centrifugation medium then half-dissolved in HBSS-1 \% PSN solution and pelleted by centrifugation at $1500 \mathrm{rpm}$ for $15 \mathrm{~min}$. The brain parenchyma pellet was then washed several times before being frozen at $-80^{\circ} \mathrm{C}$.

\section{Cell culture}

Rat primary BECs and glial cells were isolated and cultured as previously described [26]. Briefly, for BECs, brain tissues were digested enzymatically $(1 \mathrm{~g} / \mathrm{L}$ collagenase/dispase, $20 \mathrm{U} / \mathrm{mL}$ DNAse I, $0.147 \mathrm{mg} / \mathrm{L}$ TCLK in HBSS, $1 \mathrm{~h}$ at $37^{\circ} \mathrm{C}$ ). A $20 \%$ BSA gradient was used for isolation of capillaries. After a second enzymatic digestion, cells were plated in $75 \mathrm{~cm}^{2}$ coated culture flasks in EBM medium completed by the EGM-2 MV SingleQuots kit (Lonza, Basel, Switzerland). Cultures were maintained at $37{ }^{\circ} \mathrm{C}$ in a humidified $5 \% \mathrm{CO}_{2}$ atmosphere for 5-6 days before being trypsinized and frozen.

\section{BBB cell-based model}

For BBB modeling, glial cells were seeded at a density of $5700 \mathrm{cells} / \mathrm{cm}^{2}$ on transwell plates in a glial-specific basal medium as previously reported [26]. BECs were plated on the upper side of a coated polyester transwell membrane (pore size $0.4 \mathrm{~mm}$, Costar, Dutscher sa, Brumath, France) at a density of 71400 cells $/ \mathrm{cm}^{2}$ in a BEC-specific medium. Microplates were then incubated at $37{ }^{\circ} \mathrm{C}$ in a humidified $5 \% \mathrm{CO}_{2}$ atmosphere for 5 to 7 days before treatment. Upper and lower chambers will be referred to as apical and basal compartments, respectively, throughout this manuscript. 4 sera from controls and 4 sera from treated animals were tested. Each collected serum from controls and treated animals were diluted at 1/16 in the BEC medium. BECs were exposed to diluted rat serum in the apical compartment for $24 \mathrm{~h}$. Transport experiments were performed in six wells for each serum.

\section{Transport experiments}

After exposure to sera, exposure medium were removed then transwells with BECs were transferred to new plates. 0.5 and $1.5 \mathrm{~mL}$ of transfer buffer $(150 \mathrm{mM} \mathrm{NaCl}$, $5.2 \mathrm{mM} \mathrm{KCl}, 2.2 \mathrm{mM} \mathrm{CaCl}, 0.2 \mathrm{mM} \mathrm{MgCl}_{2}, 6 \mathrm{mM}$ $\mathrm{NaHCO}_{3}, 2.8 \mathrm{mM}$ glucose and $5 \mathrm{mM}$ Hepes) was added to the apical and basolateral compartments or donor and acceptor chambers, respectively. Lucifer yellow (LY) was added to the donor chamber to a final concentration 
of $0.1 \mathrm{mM}$ and, after $30 \mathrm{~min}$, aliquots from acceptor and donor chambers were collected for determination of tracer concentration by fluorescence counting. The apparent permeability $\left(\mathrm{P}_{\mathrm{app}}\right)$ value for LY was calculated as follows:

$$
\mathrm{P}_{\mathrm{app}}=\mathrm{dQ}=\mathrm{dT} \times \mathrm{A} \times \mathrm{C}_{0}
$$

where $\mathrm{dQ} / \mathrm{dT}$ is the amount of LY transported per time-point, $A$ is the membrane surface area and $C_{0}$ the initial donor concentration. The mass balance (R) was calculated as:

$$
\mathrm{R}(\%)=100 \times\left[(\mathrm{A}+\mathrm{D}) / \mathrm{D}_{0}\right]
$$

where $\mathrm{A}$ and $\mathrm{D}$ are the amounts of LY in the acceptor and donor chambers and $D_{0}$ is the amount introduced at $\mathrm{t}$ : 0 . Mass balances of LY were between 80 and $120 \%$. As LY permeability values on the order of $10^{-6} \mathrm{~cm} / \mathrm{s}$ were obtained previously in various in vitro $\mathrm{BBB}$ models $[33,56-58]$, we considered that beyond $5.10^{-6} \mathrm{~cm} / \mathrm{s}$ the monolayer is disrupted.

\section{Transcription profiling}

RNA was isolated from rat BECs, brain parenchyma fraction or cells isolated from the BBB in vitro model using the RNeasy plus universal tissue minikit or the RNeasy Mini kit, respectively (Qiagen, France), according to the manufacturer's instructions. The concentration and purity of the RNA samples were assessed spectrophotometrically at 260 and $280 \mathrm{~nm}$ using the NanoDrop ND-1000 instrument (NanoDrop Technologies, Wilmington, DE, USA). The A260/280 ratio ranged between 1.8 and 2 .

A sample of $0.5 \mu \mathrm{g}$ of total RNA was converted to cDNA with random primers in a total of $10 \mu \mathrm{L}$ using an RT2 first stand kit (Qiagen, France). The cDNA was diluted with DNA/RNAse-free distilled water to a volume of $110 \mu \mathrm{L}$.

The quantitative expression of various cytokines, chemokines, transporters and structural proteins was determined using 0.4 $\mu \mathrm{M}$ cDNA for each primer set in the RT2 Pathway Focus profiler array from Qiagen. The RT2 Profiler array consists of a previously validated qRT-PCR primer set $(1 \mu \mathrm{L})$ for relevant cytokines, chemokines: Il$1 \beta$, CXCL1 and IP-10; tight junction proteins: Cldn5 and Ocln; ABC transporters: $A b c b 1$ and $A b c g 2$ and housekeeping genes (Hprt, GAPDH). Thermocycling was carried out in a CFX96 real-time PCR detection system (Bio-Rad) using SYBR green fluorescence detection. The final reaction mixture contained $2 \mu \mathrm{L}$ of diluted cDNA, $1 \mu \mathrm{L}$ of one of the specific primer, $12.5 \mu \mathrm{L}$ of distilled water and $9.5 \mu \mathrm{L}$ of SYBR green master mix. The specific amplification conditions were $2 \mathrm{~min}$ at $50{ }^{\circ} \mathrm{C}$, $10 \mathrm{~min}$ at $95{ }^{\circ} \mathrm{C}$ followed by 40 amplification cycles at
$95{ }^{\circ} \mathrm{C}$ for $0.5 \mathrm{~min}$, and $60{ }^{\circ} \mathrm{C}$ for $1 \mathrm{~min}$ to reinitialize the cycle again. The specificity of each reaction was also assessed by melting curve analysis to ensure the presence of only one product. Relative gene expression values were calculated as $2^{-\Delta C T}$, where $\Delta C T$ is the difference between the amplification curve (CT) values for genes of interest and housekeeping genes (hypoxanthine guanine phosphoryltransferase or Hprt; glyceraldehyde phosphodehydrogenase or GAPDH). If the CT was higher than 35 , we considered the expression level too low to be applicable.

\section{Immunofluorescence}

Brain sections embedded in OCT and cut on a cryostat $(10 \mu \mathrm{m})$ were prepared for either occludin or claudin-5, and von Willebrand factor (vWF) double immunofluorescence, or IL-1 $\beta$. Brain sections were air-dried for $30 \mathrm{~min}$ and fixed in ice-cold acetone for $30 \mathrm{~min}$ and then rinsed in PBS. Sections were then incubated with $3 \%$ BSA for 60 min at RT, rinsed in PBS, and incubated with $150 \mu \mathrm{L}$ per section of the appropriate primary antibody (occludin: 1:1000, Abcam, Cambridge, MA; clauin5: 1:100, Invitrogen/Life Technologies, Carlbad, CA) and an FITC-tagged vWF (1:1000 dilution, Abcam) or IL-1 $\beta$ (1:1000, Abcam) alone; diluted in wash buffer [1 part $5 \%$ blocking solution $(0.5 \mathrm{~mL}$ normal rabbit serum in $10 \mathrm{~mL} 3 \% \mathrm{w} / v$ bovine serum albumin) and 4 parts phosphate-buffered saline (PBS)] for $1 \mathrm{~h}$ at room temperature (RT) and then rinsed 3 times with PBS. The slides were incubated in $150 \mu \mathrm{L}$ per section of the appropriate secondary antibody with either Alexa Fluor 555 or Alexa Fluor 546 (1:1000 dilution, Vector Laboratories, Biovalley, Marne la Vallée, France) in the dark for $1 \mathrm{~h}$ at RT. Slides were rinsed 3 times in PBS and subsequently incubated with Hoechst nuclear stain $(1 \mu \mathrm{L} / \mathrm{mL}$; $150 \mu \mathrm{L} /$ section) for one minute, rinsed again then coverslipped with Aqueous Gel Mount (TBS, Fisher Scientific, Waltham, MA). Slides were imaged by fluorescence microscopy at 10x and 40x, using the appropriate excitation/emission filters, digitally recorded, and analyzed by image densitometry using Image J software (NIH). A minimum of 3 locations on each section $(2$ sections per slide), 3 slides and $n=3$ per group were processed/analyzed. Only vessels $>50 \mu \mathrm{m}$ were used for analysis.

\section{Statistical Analysis}

Analyses were performed using the Prism 5.1 program (GraphPad Software, Inc, San Diego CA). Statistical comparisons conducted herein were accomplished using variance analysis (two-way ANOVA) two determinants being time and treatment for organs $\mathrm{Ti}$ distribution followed by the Bonferroni post test. mRNA expression of cytokines and chemokines were analyzed using one tailed Mann-Whitney test and two tailed Man Whitney 
test for other mRNA expressions (tight junctions proteins and transporters). Immunofluorescence end points were analyzed using one-way ANOVA between treatment groups followed by the Holm-Sidak post hoc test (SigmaPlot SyStat Software Inc, San Joes, CA) and data were expressed as mean $\pm \mathrm{SD}$. Changes were considered statistically significant at $P<0.05$.

\section{Additional files}

\section{Additional file 1: BBB integrity assessment after IV injection of} $10 \mathrm{mg} / \mathrm{kg} \mathrm{TiO}_{2} \mathrm{NPs}$ in rats. BBB integrity was estimated by the ratio between atenolol concentrations in brain and plasma (partition coefficient or Kp). Each data point represents the mean \pm SD of $n=8$ rats. Statistical comparison was performed by two tailed Mann-Whitney test, ${ }^{*} P<0.05$. (TIFF $4945 \mathrm{~kb}$ )

\section{Additional file 2: Effect of $24 \mathrm{~h} \mathrm{TiO}_{2} \mathrm{NPs}$ exposure on BEC} epithelium integrity. $\mathrm{TiO}_{2} \mathrm{NPs}$ concentrations from 0 to $100 \mu \mathrm{g} / \mathrm{mL}$ were applied to the apical pole of the in vitro BBB model for $24 \mathrm{~h}$. Data are apparent permeability coefficient of sucrose. Each data point represents the mean \pm SD of at least 2 experiments. The horizontal dotted line represents the usual limit value of $8.310^{-6} \mathrm{~cm} \cdot \mathrm{s}^{-1}$ beyond which the BEC monolayer is considered to be disrupted. The blue zone represents sucrose apparent permeability coefficient for the controls (Mean \pm SD). (TIFF $61 \mathrm{~kb}$ )

\section{Abbreviations}

$\mathrm{TiO}_{2} \mathrm{NPS}$ : Titanium dioxide nanoparticles; CNS: Central nervous system; IV: Intravenous; IL-1 $\beta$ : Interleukin-1 $\beta$; CXCL1: Chemokine Ligand 1; IP-10: Gamma inductible protein-10; BECs: Brain endothelial cells; P-gp: P-glycoprotein; BCRP: Breast cancer resistance protein; TEM: Transmission electron microscopy; SEM: Scanning electron microscopy; EDX: Energy dispersive $X$ ray; BET: Brunauer-Emmett-Teller; DLS: Dynamic light scattering; ICP-MS: Inductively couple plasma mass spectrometry; LOQ: Limit of quantification; Kp: Partition coefficient; $P_{a p p}$ : Apparent permeability; LY: Lucifer yellow; GFAP: Glial fibrillary acid protein; RT: Room temperature; TNF-a: Tumor Necrosis Factor - a; TNF-R1: Tumor necrosis factor receptor 1.

\section{Competing interest}

The authors declare that they have no competing interests.

\section{Author's contributions}

$\mathrm{CD}$ participated in the design of the studies, animal experiments, in vitro BBB studies, real-Time RT PCR studies and LC/MS/MS studies. JD and MC carried out titanium quantification studies in biological samples and analyzed final data. AC coordinated in vitro BBB studies, NH and EB carried out titanium dioxide nanoparticles characterization studies. AL participated in the study design and oversaw immunohistochemistry studies. AM conceived of the study, participated in its design and coordination and assisted with drafting the manuscript. All authors read and approved the final manuscript prior to submission.

\section{Acknowledgements}

The authors would like to thank Emilie Jaumain for her contribution in animal experiments and Gael Noyalet for LC-MS analyse. The authors would like to thank JoAnn Lucero for her contribution to this manuscript in processing and analyzing the samples for immunofluorescence. This research was supported by the University of North Texas Department of Biology. This work has benefited from the facilities and expertise of the Imagif Cell Biology Unit of the Gif campus (www.imagif.cnrs.fr).

\section{Author details}

${ }^{1}$ CEA, Direction des Sciences du Vivant, iBiTec-S, Service de Pharmacologie et d'Immunoanalyse, Equipe Pharmacologie Neurovasculaire, 91191 Gif-sur-Yvette, France. ${ }^{2}$ INRS, Département Polluants et Santé, Rue du Morvan, CS 60027, 54519 Vandœuvre Cedex, France. ${ }^{3}$ DSM, IRAMIS, NIMBE (UMR 3685), laboratory of Nanometric Structures, CEA Saclay, 91191 Gif/ Yvette, France. ${ }^{4}$ Laboratoire de Chimie Physique, UMR CNRS 8000, Université de Paris-Sud, 91405 Orsay, France. ${ }^{5}$ Department of Biological Sciences, University of North Texas, Denton, TX, USA.

Received: 30 April 2015 Accepted: 24 August 2015

Published online: 04 September 2015

\section{References}

1. Chen X, Mao SS. Titanium dioxide nanomaterials: synthesis, properties, modifications, and applications. Chem Rev. 2007;107:2891-959.

2. Weir A, Westerhoff P, Fabricius L, Hristovski K, von Goetz N. Titanium dioxide nanoparticles in food and personal care products. Environ Sci Technol. 2012;46:2242-50

3. Peters RJB, van Bemmel G, Herrera-Rivera Z, Helsper HPFG, Marvin HJP, Weigel $\mathrm{S}$, et al. Characterization of titanium dioxide nanoparticles in food products: analytical methods to define nanoparticles. J Agric Food Chem. 2014;62:6285-93

4. Brun E, Barreau F, Veronesi G, Fayard B, Sorieul S, Chaneac C, et al. Titanium dioxide nanoparticle impact and translocation through ex vivo, in vivo and in vitro gut epithelia. Part Fibre Toxicol. 2014;11:13.

5. Shi H, Magaye R, Castranova V, Zhao J. Titanium dioxide nanoparticles: a review of current toxicological data. Part Fibre Toxicol. 2013;10:15.

6. lavicoli I, Leso V, Bergamaschi A. Toxicological effects of titanium dioxide nanoparticles: a review of in vivo studies. Journal of Nanomaterials. 2012;15(5):481-508.

7. Abbott NJ, Ronnback L, Hansson E. Astrocyte-endothelial interactions at the blood-brain barrier. Nat Rev Neurosci. 2006;7:41-53.

8. Abbott NJ, Patabendige AAK, Dolman DEM, Yusof SR, Begley DJ. Structure and function of the blood-brain barrier. Neurobiol Dis. 2010;37:13-25.

9. Abbott NJ, Friedman A. Overview and introduction: the blood-brain barrier in health and disease. Epilepsia. 2012;53:1-6.

10. Abbott NJ. Blood-brain barrier structure and function and the challenges for CNS drug delivery. J Inherit Metab Dis. 2013;36:437-49.

11. Keller A. Breaking and building the wall: the biology of the blood-brain barrier in health and disease. Swiss Med Wkly. 2013;143:w13892.

12. Begley DJ. ABC transporters and the blood-brain barrier. Curr Pharm Des. 2004;10:1295-312.

13. Loscher W, Potschka $H$. Role of drug efflux transporters in the brain for drug disposition and treatment of brain diseases. Prog Neurobiol. 2005;76:22-76.

14. Omidi Y, Barar J. Impacts of blood-brain barrier in drug delivery and targeting of brain tumors. Biolmpacts. 2012;2:5-22.

15. Fabian E, Landsiedel R, Ma-Hock L, Wiench K, Wohlleben W, van Ravenzwaay B. Tissue distribution and toxicity of intravenously administered titanium dioxide nanoparticles in rats. Arch Toxicol. 2008;82:151-7.

16. Shinohara N, Danno N, Ichinose T, Sasaki T, Fukui H, Honda K, et al. Tissue distribution and clearance of intravenously administered titanium dioxide (TiO(2)) nanoparticles. Nanotoxicology. 2013;8(2):132-41.

17. Xie G, Wang C, Sun J, Zhong G. Tissue distribution and excretion of intravenously administered titanium dioxide nanoparticles. Toxicol Lett. 2011;205:55-61.

18. Geraets $L$, Oomen AG, Krystek $P$, Jacobsen NR, Wallin $H$, Laurentie M, et al. Tissue distribution and elimination after oral and intravenous administration of different titanium dioxide nanoparticles in rats. Part Fibre Toxicol. 2014;11:30.

19. Wang J, Zhou G, Chen C, Yu H, Wang T, Ma Y, et al. Acute toxicity and biodistribution of different sized titanium dioxide particles in mice after oral administration. Toxicol Lett. 2007;168:176-85

20. Wang J, Chen C, Liu Y, Jiao F, Li W, Lao F, et al. Potential neurological lesion after nasal instillation of $\mathrm{TiO}(2)$ nanoparticles in the anatase and rutile crystal phases. Toxicol Lett. 2008:183:72-80.

21. Takahashi Y, Mizuo K, Shinkai Y, Oshio S, Takeda K. Prenatal exposure to titanium dioxide nanoparticles increases dopamine levels in the prefrontal cotex and neostriatum of mice. J Toxicol Sci. 2010;35:749-56.

22. Shin JA, Lee EJ, Seo SM, Kim HS, Kang JL, Park EM. Nanosized titanium dioxide enhanced inflammatory responses in the septic brain of mouse. Neuroscience. 2010;165:445-54.

23. Ze $Y$, Zheng $L$, Zhao $X$, Gui S, Sang $X$, Su J, et al. Molecular mechanism of titanium dioxide nanoparticles-induced oxidative injury in the brain of mice. Chemosphere. 2013;92:1183-9.

24. Ze Y, Hu R, Wang X, Sang X, Ze X, Li B, et al. Neurotoxicity and geneexpressed profile in brain-injured mice caused by exposure to titanium dioxide nanoparticles. J Biomed Mater Res A. 2014;102:470-8. 
25. Shrivastava R, Raza S, Yadav A, Kushwaha P, Flora SJS. Effects of sub-acute exposure to $\mathrm{TiO} 2, \mathrm{ZnO}$ and $\mathrm{Al} 2 \mathrm{O} 3$ nanoparticles on oxidative stress and histological changes in mouse liver and brain. Drug Chem Toxicol. 2014:37:336-47.

26. Lacombe O, Videau O, Chevillon D, Guyot A-C, Contreras C, Blondel S, et al. In vitro primary human and animal cell-based blood-brain barrier models as a screening tool in drug discovery. Mol Pharm. 2011;8:651-63.

27. Brun $\mathrm{E}$, Carriere M, Mabondzo A. In vitro evidence of dysregulation of blood-brain barrier function after acute and repeated/long-term exposure to TiO(2) nanoparticles. Biomaterials. 2012;33:886-96.

28. van Ravenzwaay B, Landsiedel R, Fabian E, Burkhardt S, Strauss V, Ma-Hock $L$. Comparing fate and effects of three particles of different surface properties: nano-TiO2, pigmentary $\mathrm{TiO} 2$ and quartz. Toxicol Lett. 2009;186:152-9.

29. Harati R, Benech H, Villegier AS, Mabondzo A. P-Glycoprotein, breast cance resistance protein, organic anion transporter 3 , and transporting peptide 1a4 during blood-brain barrier maturation: involvement of Wnt/betaCatenin and Endothelin-1 signaling. Mol Pharm. 2013;10:1566-80.

30. Daneman R. The blood-brain barrier in health and disease. Ann Neurol. 2012;72:648-72.

31. van Vliet EA, Araujo SC, Redeker S, van Schaik R, Aronica E, Gorter JA. Bloodbrain barrier leakage may lead to progression of temporal lobe epilepsy. Brain. 2007;130:521-34

32. Marchi N, Granata T, Alexopoulos A, Janigro D. The blood-brain barrier hypothesis in drug resistant epilepsy. Brain. 2012;135(Pt 4):e211.

33. Hellinger $E$, Veszelka S, Toth AE, Walter F, Kittel A, Bakk ML, et al. Comparison of brain capillary endothelial cell-based and epithelial (MDCK-MDR1, Caco-2, and VB-Caco-2) cell-based surrogate blood-brain barrier penetration models. Eur J Pharm Biopharm. 2012;82:340-51.

34. Wang X, Campos CR, Peart JC, Smith LK, Boni JL, Cannon RE, et al. Nrf2 upregulates ATP binding cassette transporter expression and activity at the blood-brain and blood-spinal cord barriers. J Neurosci. 2014;34:8585-93.

35. Sugimoto $H$, Hirabayashi $H$, Amano N, Moriwaki T. Retrospective analysis of P-Glycoprotein-Mediated Drug-drug interactions at the blood-brain barrier in humans. Drug Metab Dispos. 2013;41:683-8.

36. Schinkel $A H$, Wagenaar $E$, Vandeemter $L, M o l ~ C$, Borst $P$. Absence of the MDR1A P-Glycoprotein in mice affects tissue distribution and pharmacokinetics of dexamethasone, digoxin, and cyclosporine-A. J Clin Invest. 1995;96:1698-705

37. Schinkel AH, Mayer U, Wagenaar E, Mol C, van Deemter L, Smit JJM, et al. Normal viability and altered pharmacokinetics in mice lacking mdr1-type (drug-transporting) P-glycoproteins (vol 94, pg 4028, 1997). Proc Natl Acad Sci U S A. 2003;100:8036-6.

38. Mayer U, Wagenaar E, Dorobek B, Beijnen JH, Borst P, Schinkel AH. Full blockade of intestinal P-glycoprotein and extensive inhibition of blood-brain barrier P-glycoprotein by oral treatment of mice with PSC833. J Clin Invest. 1997:100:2430-6.

39. Liu Y-C, Liu H-Y, Yang H-W, Wen T, Shang Y, Liu X-D, et al. Impaired expression and function of breast cancer resistance protein (Bcrp) in brain cortex of streptozocin-induced diabetic rats. Biochem Pharmacol. 2007:74:1766-72

40. Hartz AMS, Bauer B, Fricker G, Miller DS. Rapid modulation of p-glycoprotein-mediated transport at the blood-brain barrier by tumor necrosis factor-alpha and lipopolysaccharide. Mol Pharmacol. 2006:69:462-70

41. Miller DS. Regulation of ABC transporters blood-brain barrier: the good, the bad, and the ugly. Adv Cancer Res. 2015;125:43-70.

42. Ma L, Liu J, Li N, Wang J, Duan Y, Yan J, et al. Oxidative stress in the brain of mice caused by translocated nanoparticulate $\mathrm{TiO} 2$ delivered to the abdominal cavity. Biomaterials. 2010;31:99-105.

43. Carvalho da Fonseca AC, Matias D, Garcia C, Amaral R, Geraldo LH, Freitas C, et al. The impact of microglial activation on blood-brain barrier in brain diseases. Front Cell Neurosci. 2014;8:362.

44. Miller DS. Regulation of P-glycoprotein and other ABC drug transporters at the blood-brain barrier. Trends Pharmacol Sci. 2010;31:246-54.

45. Bauer B, Hartz AMS, Miller DS. Tumor necrosis factor alpha and endothelin-1 increase P-glycoprotein expression and transport activity at the blood-brain barrier. Mol Pharmacol. 2007;71:667-75.

46. Sha B, Gao W, Wang S, Gou X, Li W, Liang X, et al. Oxidative stress increased hepatotoxicity induced by nano-titanium dioxide in BRL-3A cells and Sprague-Dawley rats. J Appl Toxicol. 2014;34:345-56.
47. Wang Y, Chen ZJ, Ba T, Pu J, Cui XX, Jia G. Effects of TiO2 nanoparticles on antioxidant function and element content of liver and kidney tissues in young and adult rats. Journal of Peking University Health sciences. 2014:46:395-9.

48. Hong J, Wang $L$, Zhao X, Yu X, Sheng $L, X u$ B, et al. Th2 factors may be involved in $\mathrm{TiO}_{2} \mathrm{NP}$-induced hepatic inflammation. J Agric Food Chem. 2014;62:6871-8.

49. Didier N, Romero IA, Creminon C, Wijkhuisen A, Grassi J, Mabondzo A. Secretion of interleukin-1 beta by astrocytes mediates endothelin-1 and tumour necrosis factor-alpha effects on human brain microvascular endothelial cell permeability. J Neurochem. 2003;86:246-54.

50. Argaw AT, Zhang Y, Snyder BJ, Zhao M-L, Kopp N, Lee SC, et al. IL-1beta regulates blood-brain barrier permeability via reactivation of the hypoxia-angiogenesis program. J Immunol. 2006;177:5574-84

51. Labus J, Haeckel S, Lucka L, Danker K. Interleukin-1 beta induces an inflammatory response and the breakdown of the endothelial cell layer in an improved human THBMEC-based in vitro blood-brain barrier model. J Neurosci Methods. 2014;228:35-45.

52. Poller B, Drewe J, Krahenbuhl S, Huwyler J, Gutmann H. Regulation of BCRP (ABCG2) and P-glycoprotein (ABCB1) by cytokines in a model of the human blood-brain barrier. Cell Mol Neurobiol. 2010;30:63-70.

53. Zhang K, Tian L, Liu L, Feng Y, Dong Y-B, Li B, et al. CXCL1 contributes to beta-Amyloid-induced transendothelial migration of monocytes in Alzheimer's disease. PloS One. 2013;8(8):e72744.

54. Campbell IL, Erta M, Lim SL, Frausto R, May U, Rose-John S, et al. Transsignaling is a dominant mechanism for the pathogenic actions of Interleukin-6 in the brain. J Neurosci. 2014;34:2503-13.

55. Harati R, Villegier A-S, Banks WA, Mabondzo A. Susceptibility of juvenile and adult blood-brain barrier to endothelin-1: regulation of P-glycoprotein and breast cancer resistance protein expression and transport activity. J Neuroinflammation. 2012:9:273.

56. Cecchelli R, Berezowski V, Lundquist S, Culot M, Renftel M, Dehouck M-P, et al. Modelling of the blood-brain barrier in drug discovery and development. Nat Rev Drug Discov. 2007;6:650-61.

57. Deli MA, Abraham CS, Kataoka Y, Niwa M. Permeability studies on in vitro blood-brain barrier models: physiology, pathology, and pharmacology. Cell Mol Neurobiol. 2005;25:59-127.

58. Reichel A, Begley DJ, Abbott NJ. An overview of in vitro techniques for blood-brain barrier studies. Methods Mol Med. 2003:89:307-24.

\section{Submit your next manuscript to BioMed Central and take full advantage of:}

- Convenient online submission

- Thorough peer review

- No space constraints or color figure charges

- Immediate publication on acceptance

- Inclusion in PubMed, CAS, Scopus and Google Scholar

- Research which is freely available for redistribution 